Article

\title{
Forest Fragmentation in the Lower Amazon Floodplain: Implications for Biodiversity and Ecosystem Service Provision to Riverine Populations
}

\author{
Vivian Renó ${ }^{1, *}$, Evlyn Novo ${ }^{1}$ and Maria Escada ${ }^{2}$ \\ 1 Remote Sensing Division (DSR), Brazilian Institute for Space Research (INPE), Av. dos Astronautas 1758, \\ São José dos Campos 12227-010, São Paulo, Brazil; evlyn.novo@inpe.br \\ 2 Image Processing Division (DPI), Brazilian Institute for Space Research (INPE), Av. dos Astronautas 1758, \\ São José dos Campos 12227-010, São Paulo, Brazil; isabel.escada@inpe.br \\ * Correspondence: vivian.reno@inpe.br; Tel.: +55-12-3208-64-86
}

Academic Editors: Parth Sarathi Roy and Prasad S. Thenkabail

Received: 1 July 2016; Accepted: 17 October 2016; Published: 27 October 2016

\begin{abstract}
This article analyzes the process of forest fragmentation of a floodplain landscape of the Lower Amazon over a 30-year period and its implications for the biodiversity and the provision of ecosystem services to the riverine population. To this end, we created a multi-temporal forest cover map based on Landsat images, and then analyzed the fragmentation dynamics through landscape metrics. From the analyses of the landscape and bibliographic information, we made inferences regarding the potential impacts of fragmentation on the biodiversity of trees, birds, mammals and insects. Subsequently, we used data on the local populations' environmental perception to assess whether the inferred impacts on biodiversity are perceived by these populations and whether the ecosystem services related to the biodiversity of the addressed groups are compromised. The results show a $70 \%$ reduction of the forest habitat as well as important changes in the landscape structure that constitute a high degree of forest fragmentation. The perceived landscape alterations indicate that there is great potential for compromise of the biodiversity of trees, birds, mammals and insects. The field interviews corroborate the inferred impacts on biodiversity and indicate that the ecosystem services of the local communities have been compromised. More than $95 \%$ of the communities report a decreased variety and/or abundance of animal and plant species, $46 \%$ report a decrease in agricultural productivity, and 19\% confirm a higher incidence of pests during the last 30 years. The present study provides evidence of an accelerated process of degradation of the floodplain forests of the Lower Amazon and indicate substantial compromise of the ecosystem services provision to the riverine population in recent decades, including reductions of food resources (animals and plants), fire wood, raw material and medicine, as well as lower agricultural productivity due to probable lack of pollination, impoverishment of the soil and an increase of pests.
\end{abstract}

Keywords: Amazon floodplain; forest fragmentation; remote sensing; biodiversity; ecosystem services; riverine population

\section{Introduction}

The human being depends on a wide variety of ecosystem services (ES) for its survival and well-being. Ecosystems are sources of indispensable resources such as food and water, and they also provide other important services such as pollination, erosion control, and air and water purification, among others [1,2]. Many of these services have supported the growing demands of modern societies. Currently, however, the majority of the ES on the planet are in decline due to anthropogenic disturbances $[1,3]$. 
The floodplains of the Amazon region are among the most complex ecosystems on the planet, characterized by high level of biodiversity and productivity [4,5], occupying about $840,000 \mathrm{~km}^{2}$ [6]. Despite representing a small fraction of the Amazon $(<4 \%)$, these ecosystems are historically responsible for the provision of various goods and ES to the population [4,5]. Examples of these resources include water supply directly from rivers and channels, river transport, fishing, hunting, and the provision of wood, fruit and vegetables consumed by the population [7-10].

The riverine populations are especially dependent on floodplain resources and it is estimated that currently about 1.8 million people live in the floodplains of Amazonas and Pará States [11]. Their communities are embedded in the floodplain and, therefore, the activities of forest resource extraction, small-scale agriculture, animal production, cattle ranching, hunting and fishing constitute their means of subsistence [12]. Despite the scarcity of studies on the Amazon floodplains specifically, research conducted in other tropical wetlands shows that their products are crucial to local subsistence, contributing almost two thirds of the family income in some areas [4].

The socio-ecological functions of the floodplains are sensitive to a wide variety of anthropogenic activities [13]. This sensitivity enhances the impacts of human action, which is the factor responsible for almost all direct and indirect modification of the wetland areas in developed countries $[14,15]$. The Amazon floodplains also suffer degradation due to the removal of its forests, particularly in its lower reaches [16,17]. During the 19th century, large areas of the floodplain in the Lower Amazon region were deforested to make space for cacao plantations [18] and, since the beginning of the 20th century, have been used intensively for timber exploitation, agriculture and cattle ranching [12,18-21]. Recent studies show that the floodplain forest area in the Lower Amazon region decreased by about $50 \%$ between the end of the 1970s and 2008 [17], accompanied by significant alterations in the landscape structure [22].

Different authors [23-26] report that the structure of a given landscape is closely related to the integrity of its ecosystems and, therefore, to its capacity to provide ES (e.g., large forest patches are related to high mammals diversity, which play an important role as pollinators, seed dispersers, pest and disease regulators and food for the local population). Considering the severe alterations suffered by floodplain environments in recent decades, understanding the effects of such alterations on the provision of ES to the riverine population is vital, especially given the great dependence of such populations on the environment in which they live. However, one of the difficulties in evaluating this issue are the costs and complexity of the methods used to assess the supply of ES within a given landscape. Many of these methods are costly, as they require lengthy fieldwork to collect material, measure biotic and abiotic parameters and exhaustively sample animal and plant species.

Assuming that the landscape structure has a strong influence on the supply of ES to the population, an alternative for assessing these services would be the use of landscape analysis methods. Currently, there is a considerable amount of studies that related landscape structure to ecological data collected in the field, with the intent to better understanding the relationship between landscape structure as ES provision [27-31]. These studies take a bottom-up approach and are important for identifying the landscape configurations (metrics and thresholds) with the greatest impact on various ES. This knowledge supports the realization of top-down studies, through which landscape structure can be used to infer the provision of ES [32-36]. Despite that the human being is explicit in the concept of ES, many studies focus only on the ecological aspects, excluding from the analysis the final beneficiary of the services delivered by nature. According to the Millennium Ecosystem Assessment [1], the studies and analyses of ES must consider not only the ecosystems responsible for the supply of services, but also the people that depend and are affected by the changes in their supply, thus linking the environment and the development fields.

In this context, the present study combines the top-down approach with interview data from riverine populations of the Lower Amazon, with the purpose of: (1) inferring the effects of floodplain forest fragmentation on the maintenance of biodiversity of key ecological groups; and (2) assessing the perception of the riverine residents in relation to the endangerment of ES related to the biodiversity 
of the studied groups. In this study, we treat biodiversity as a supportive ES necessary for the production of the ES used by the riverine communities, such as food, medicine, fuel wood, raw material and pollination, among others. The impacts of fragmentation on biodiversity and ES will not be assessed directly, but will be inferred based on the landscape structure and the interviews with the riverine population.

The proposed approach represents a tool for prospecting the strain of biodiversity and of ES provision to human populations in extensive, remote and relatively under-studied areas such as the floodplains of the Amazon basin. The results help direct future scientific works and policies for the management of the Amazon floodplain, with a view to improve the contribution from floodplain ecosystems to human well-being without affecting its integrity and provision capacity in the long term.

\section{Study Area}

The study area occupies about $9000 \mathrm{~km}^{2}$ of floodplain and extends for $200 \mathrm{~km}$ along the Amazon River. It is situated in Pará State (PA), Brazil, and includes parts of the municipalities of Alenquer, Santarém, Monte Alegre and Prainha (Figure 1). The area is part of the Lower Amazon region, which extends from the boundary between the States of Amazonas and Pará to the confluence of the Xingu River [21].

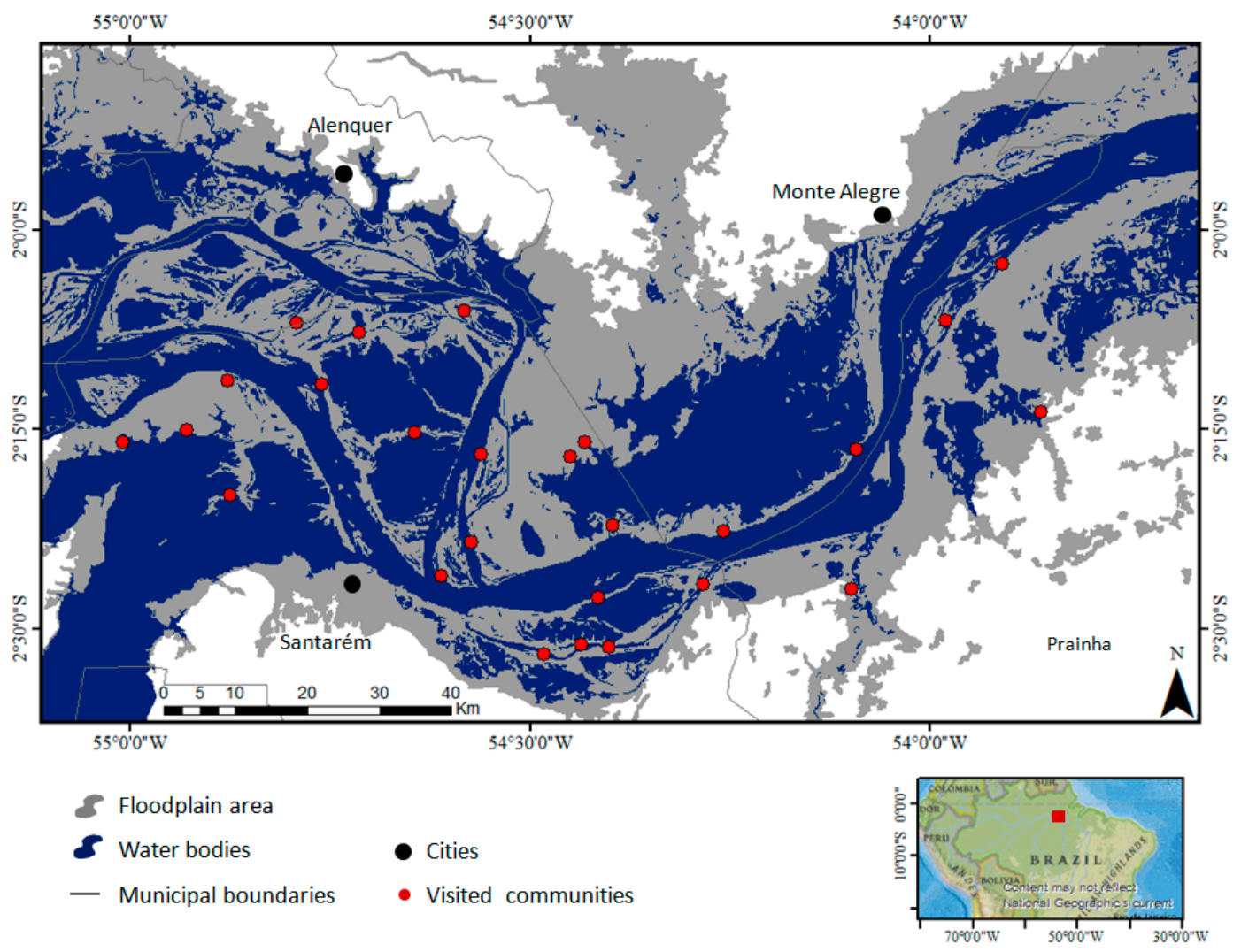

Figure 1. Location and extension of the study area in the floodplain region of the Lower Amazon, among the cities of Alenquer, Santarém and Monte Alegre, Pará State, Brazil.

The vegetation cover is diverse, consisting of a mixture of mature forest, forest in regeneration, natural grassland, semi-aquatic macrophytes and cultivated areas $[12,18]$. The flood pulse of the Amazon River is the main ecological forcing in the floodplain [37], responsible for the seasonal fluctuation of the water level. The river begins to rise in November (rising-water), reaching its maximum level between the end of May and the beginning of June (high-water), and descending again during the following months (falling-water), reaching its lowest level at the end of October or beginning of November (low-water) [38]. 
The patterns of land use and human occupation are related to the topography, the vegetation and the level of inundation. The settlements and most agricultural activities are concentrated on the levees, with communities distributed along the margins of the Amazon River and some of its tributaries. The property boundaries are aligned perpendicular to the river, such that the majority of housing units have access to the principal "ecozones" of the floodplain (rivers, levees, grasslands and lakes). Agriculture is typically practiced on the levees under private control, while fishing is practiced in rivers and lakes with public access. Cattle ranching activity alternates between the floodplain pastures and the upland pastures, according to the period of inundation [12,18]. Settlements and agriculture activities are mostly related to small landowners, while much of the livestock is from large landowners of the uplands.

\section{Materials and Methods}

To infer the effects of forest fragmentation on the provision of ES to the riverine population, this study used remote sensing data, landscape analysis methods, data from the literature, as well as data regarding the environmental perception of the riverine populations. First, we defined the ES to be assessed and reviewed the literature to identify the relationship between the ES and landscape structure. Next, we produce multi-temporal maps of the study area's forest cover and analyzed the landscape structure dynamics. The landscape analysis results related to the theoretical background allowed us to make inferences about the potential impacts of forest fragmentation on the provision of the respective ES; finally, we used the environmental perception data from the local populations to evaluate the convergence between the inferred impacts and the impacts perceived by the communities in the region. A more detailed explanation of each step is given as follows.

\subsection{Definition of Ecosystem Services}

Given the importance of the floodplain forest to the local population, the focus of the research is on ES that are dependent on the forest habitat and fundamental to the well-being of the local communities: food (hunting, fruit), wood (fuel), raw material (construction of shelter, boats and artifacts), medicines (plants and animals), biological control, pollination and soil nutrient cycling. To make inferences about the ES based on the landscape, it was essential that their relationships with the landscape were documented in the literature. However, landscape analyses that deal directly with ES are rare, with the exception of some studies on pollination and biological control. To overcome the lack of information and assuming that the selected ES are dependent on the biodiversity of some ecological groups, we focused the landscape analyses on the biodiversity of four distinct ecological groups: trees, birds, mammals and insects. Thus, biodiversity is intended as a support ES necessary for the generation of the rest of the ES of interest. As such, the biodiversity ES is inferred from the landscape analysis and the rest of the ES (food, raw materials, medicine, biological control, pollination and nutrient cycling) are inferred from the perception of the riverine communities.

\subsection{Literature Review}

We searched the literature for relevant scientific articles and reviews published between 1980 and 2015 using the following keywords: forest fragmentation, landscape structure, ecosystem services and biodiversity. We searched the following databases: Google Scholar, Scopus, Capes and Web of Science. The literature cited in the identified publications was also reviewed with the objective of finding additional references of interest. Our review was constrained to scientific articles that approach the relationship between the habitat structure and the biodiversity of species and ecological groups relevant to the floodplain region. Furthermore, we selected only the studies that presented quantitative results, both in relation to the landscape parameters as well as the impacts on biodiversity. We also prioritized studies conducted in the Amazon region, Atlantic Forest and the other tropical and temperate forests, respectively. In total, we reviewed 34 studies (Table S1 in Supplementary Materials) that had been conducted in the past 25 years; 22 of these refer to the Amazon region (upland), four to 
the Atlantic Forest, four to tropical areas, and four to temperate areas. Based on this theoretical frame of reference, it was possible to identify the most appropriate parameters of the landscape structure (metrics and thresholds) to assess the biodiversity of each selected group (Table 1), in addition to compiling the main impacts of forest fragmentation on each group (Tables 2-5). It should be noted, however, that although the majority of the reviewed studies are about the Amazon region, we did not find studies specific to the floodplain areas.

Table 1. Landscape parameters (metrics and thresholds) of greatest impact on the biodiversity of trees, birds, mammals and insects, following the literature reviewed.

\begin{tabular}{ccccccc}
\hline \multirow{2}{*}{ Biodiversity } & \multicolumn{4}{c}{ Landscape Parameters (Metrics and Thresholds) } & Data Sources \\
\cline { 2 - 7 } & Habitat \% & Patch Size & Edge Width & Isolation Length & Isolation Time \\
\hline Trees & - & $1-2-100$ ha & $60-100-300 \mathrm{~m}$ & $*$ & $14-20$ years & {$[39-45]$} \\
Birds & - & $1-10-100$ ha & $50 \mathrm{~m}$ & $0-75-100-300-425 \mathrm{~m}$ & - & {$[42,46-52]$} \\
Mammals & - & $100 \mathrm{ha}$ & $50-100-180 \mathrm{~m}$ & $300 \mathrm{~m}$ & - & {$[48,53-57]$} \\
Insects & $20 \%-70 \%$ & $0.3-1-10$ ha & $50-100-200-300 \mathrm{~m}$ & $50-100-200-500-800 \mathrm{~m}-1 \mathrm{~km}$ & - \\
\hline
\end{tabular}

* Not defined value.

Table 2. Compilation of the main impacts of forest fragmentation on the biodiversity of trees, following the literature reviewed.

\begin{tabular}{|c|c|c|c|c|c|c|}
\hline & $\begin{array}{c}\text { Mortality, Damage, } \\
\text { Turnover }\end{array}$ & Canopy Gaps & $\begin{array}{c}\text { Functional } \\
\text { Diversity }\end{array}$ & $\begin{array}{c}\text { Species } \\
\text { Diversity }\end{array}$ & $\begin{array}{c}\text { Species } \\
\text { Richness }\end{array}$ & $\begin{array}{c}\text { Pioneers } \\
\text { Abundance }\end{array}$ \\
\hline \multicolumn{7}{|l|}{ Patch size } \\
\hline 2 ha & $300 \% \uparrow[41,42]$ & - & $36 \% \downarrow[39]$ & $44 \% \downarrow[39]$ & $45 \% \downarrow[43]$ & $400 \% \uparrow[44]$ \\
\hline 100 ha & $50 \% \uparrow[41,42]$ & - & $20 \% \downarrow[39]$ & $20 \% \downarrow[39]$ & - & $* \uparrow[39]$ \\
\hline \multicolumn{7}{|l|}{ Edge width } \\
\hline $0-60 \mathrm{~m}$ & $189 \% \uparrow[41,42]$ & $500 \% \uparrow[40,42]$ & - & - & - & - \\
\hline $10-100 \mathrm{~m}$ & - & - & - & - & - & $75 \% \uparrow[39]$ \\
\hline $60-100 \mathrm{~m}$ & $64 \% \uparrow[41,42]$ & - & - & - & - & - \\
\hline $100-300 \mathrm{~m}$ & $18 \% \uparrow[41,42]$ & - & - & - & - & - \\
\hline \multicolumn{7}{|c|}{ Isolation length } \\
\hline$>0 \mathrm{~m}\left({ }^{*}\right)$ & - & - & - & $* \downarrow[66]$ & ${ }^{*} \downarrow^{\mathrm{a}}[43]$ & - \\
\hline \multicolumn{7}{|l|}{ Isolation time } \\
\hline $1-20$ years & - & - & - & - & - & $* \uparrow[44]$ \\
\hline 14 years & \multicolumn{6}{|c|}{ Phylogenetic dispersion $=50 \% \downarrow[45] /$ Genus richness $=2.3 \% \downarrow[45]$} \\
\hline
\end{tabular}

Table 3. Compilation of the main impacts of forest fragmentation on the biodiversity of birds, following the literature reviewed.

\begin{tabular}{cccc}
\hline & Gap-Crossing Movements & Species Richness & Species Abundance \\
\hline Patch size & & & \\
$1 \mathrm{ha}$ & - & $86 \% \downarrow[46]$ & $94 \% \downarrow[49-52]$ \\
$10 \mathrm{ha}$ & - & - & $71 \% \downarrow[49-52]$ \\
$100 \mathrm{ha}$ & - & $* \downarrow[42,48]$ & $28 \% \downarrow[49-52]$ \\
\hline Edge width & & & - \\
$0-50 \mathrm{~m}$ & $37 \% \downarrow[47]$ & - & - \\
\hline Isolation length & $66 \% \downarrow[47]$ & - & $100 \% \downarrow(1 \mathrm{ha}) ; 30 \% \downarrow(10 \mathrm{ha})[51]$ \\
$>0 \mathrm{~m}$ & - & - & $100 \% \downarrow(1 \mathrm{ha}) ; 30 \% \downarrow(10 \mathrm{ha})[51]$ \\
$>75 \mathrm{~m}$ & - & $30 \% \downarrow[47]$ & - \\
$>100 \mathrm{~m}$ & $100 \% \downarrow[47]$ & - & - \\
$>300 \mathrm{~m}$ & & & \\
$>425 \mathrm{~m}$ & & & \\
\hline
\end{tabular}

\footnotetext{
${ }^{*}$ Not defined value. $\downarrow=$ lower than control sites. Control sites = continuous forest or forest interior (core).
} 
Table 4. Compilation of the main impacts of forest fragmentation on the biodiversity of mammals, following the literature reviewed.

\begin{tabular}{ccc}
\hline & Species Richness & Species Abundance \\
\hline Patch size & $* * 90 \%[55]$ & \\
100 ha & $83 \% \downarrow ; 100 \% \downarrow^{\text {a }[55]}$ & - \\
\hline Edge width & $* * 74 \%[56]$ & $* * 83 \%[55]$ \\
$0-50 \mathrm{~m}$ & $* \downarrow[55]$ & - \\
$0-100 \mathrm{~m}$ & - & $* \downarrow[55]$ \\
$0-180 \mathrm{~m}$ & $78 \% \downarrow[57]$ & $94 \% \downarrow[57]$ \\
\hline Isolation length & & \\
$>300 \mathrm{~m}$ & $50 \% \downarrow[53]$ & -
\end{tabular}

* Not defined value; ** percentage of variability explained. ${ }^{a}$ Large and sensitive mammals (e.g., jaguars, otters, large-bodied xenarthrans and ungulates). $\downarrow=$ lower than control sites. Control sites $=$ continuous forest or forest interior (core).

Table 5. Compilation of the main impacts of forest fragmentation on the biodiversity of insects, following the literature reviewed.

\begin{tabular}{|c|c|c|c|c|c|c|c|c|}
\hline & \multicolumn{3}{|c|}{ Herbivores } & \multicolumn{3}{|c|}{ Parasitoids } & \multicolumn{2}{|c|}{ Pollinators } \\
\hline & Richness & Abundance & $\begin{array}{l}\text { Herbivory (h) } \\
\text { Invasion (i) }\end{array}$ & Richness & Parasitism & $\begin{array}{c}\text { Host } \\
\text { Mortality }\end{array}$ & $\begin{array}{l}\text { Diversity (d) } \\
\text { Richness (r) }\end{array}$ & Visitation \\
\hline \multicolumn{9}{|l|}{ Patch size } \\
\hline 1 ha & - & - & - & $80 \% \downarrow[68]$ & - & & - & - \\
\hline 10 ha & - & - & - & - & $50 \%-100 \% \downarrow^{\mathrm{f}}[68]$ & & - & - \\
\hline \multicolumn{9}{|c|}{ Edge width } \\
\hline $200 \mathrm{~m}$ & - & - & $\mathrm{i}^{*} \uparrow \mathrm{b}[42,62]$ & - & - & - & - & - \\
\hline $300 \mathrm{~m}$ & - & - & $\mathrm{i}^{*} \uparrow^{\mathrm{c}}[42,48]$ & - & - & - & $\mathrm{d}^{*} \downarrow[42,48]$ & - \\
\hline \multicolumn{9}{|c|}{ Isolation length } \\
\hline$>50 \mathrm{~m}$ & - & - & - & - & - & - & - & $9 \% \downarrow[66]$ \\
\hline$>100 \mathrm{~m}$ & $25 \% \downarrow[68]$ & - & - & - & $50 \% \downarrow[68]$ & - & - & $56 \% \downarrow^{\mathrm{d}}[67]$ \\
\hline$>200 \mathrm{~m}$ & $50 \% \downarrow[68]$ & - & - & $100 \% \downarrow[68]$ & $100 \% \downarrow[68]$ & - & - & - \\
\hline
\end{tabular}

\subsection{Temporal Mapping of Forest Cover}

The mapping was based on a set of eight TM/MSS Landsat images (2008, 2004, 2001, 1997, 1992, 1987, 1980 and 1975) acquired over an average interval of five (5) years and covering a period of approximately 35 years. The range of water-level variation between scenes of higher $(1975,6.97 \mathrm{~m})$ and lower $(1980,2.19 \mathrm{~m}$ ) levels was $4.78 \mathrm{~m}$. This water-level variation is enough to temporarily expose most of the floodplain lake beds during low-water and to cover much of the shrubs and herbaceous vegetation during high-water. However, forest mapping is not affected by water-level fluctuations [17], since dominant forest species are between 10 and $45 \mathrm{~m}$ tall [71,72], and tend to occupy areas of higher elevation in the foodplain [71,73].

The images were submitted to object-oriented analysis techniques including multiresolution segmentation algorithms (multi-date approach) and fuzzy logic supervised classifiers [74]. Multidate segmentation was designed by Desclée et al. [75] in order to apply object-based image analysis to forest change detection studies. The method consists of the simultaneous segmentation of images from different dates, and relies on spatial, spectral and temporal information to delineate suitable objects. Since a single set of objects is created by this process, all objects match spatially among all dates. The segmentation algorithm used was based on a bottom-up region merging technique [76], as implemented in the eCognition software [77]. A Nearest Neighbor supervised classification 
algorithm based on fuzzy logic [76] was used. The algorithm uses a set of user-defined samples to assign membership values between 0 and 1 for all specified classes, based on the feature space distance from each image object to its nearest neighbor among the samples [77]. Each image was classified independently, based on samples for the following classes: floodplain forest, referring to the vegetation cover dominated by tree species; water bodies, referring to open water surface of rivers, lakes and channels; unobserved, referring to any type of cover such as exposed soil, urban area and other types of vegetation; and cloud, related to areas covered by clouds and shadows. The classification of images was restricted to only the floodplain areas, which were defined based on a wetland mask produced by Hess et al. [78] and Melack and Hess [79] and corrected by Rennó et al. [80] and Ferreira et al. [81]. After initial classification, some misclassified objects (e.g., cloud shadows wrongly classified as water) were corrected by visual inspection and manual editing. Next, the objects that presented cloud cover on a certain date were reclassified, being attributed to a class corresponding to a previous date, producing maps free of cloud cover. The removal of clouds was necessary to avoid the creation of artificial patterns in the landscape structure analysis. However, the percentage of clouds in the images is less than $9 \%$ of the study area, with less than $2 \%$ in $63 \%$ of the images. The mapping methodology used in this work was adapted from Renó et al. [17] and Novo [82].

After the classification process, Google Earth images and a set of pre-existing field data were used to estimate classification accuracy. The field data set includes two types of data collected by Renó et al. [17] during two field campaigns carried out in 2009: (a) human settlement interviews, especially among the elderly, to collect information on currently and historical land cover type (around 30 years ago); and (b) botanical observations (including vegetation structure, species composition and diversity) which indicated the current land cover type and helped reconstruct its approximate evolution over the past $\sim 30$ years, since floristic composition and structure can be diagnostic of stand age, formation type, successional stage and possible disruptions/degradations occurred in the past [17]. Based on these data, confusion matrices were built and used to estimate classification accuracy through calculation of the Kappa index of agreement. The overall accuracy of the maps ranged from 0.77 to 0.75 among the most ancient and recent maps respectively, while partial Kappa indices for the forest class ranged from 0.83 to 0.75 .

Landscape analysis: The landscape analysis was based on a set of configuration metrics (Table 6) applied to a temporal series of the generated maps (forest class). The metrics were selected based on the literature review with the objective of assessing the degree of landscape fragmentation from the perspective of the selected ecological groups (Table 1). The calculation of the metrics was performed in ArcGis [83] and Fragstats [84].

Table 6. Metrics used to assess the landscape dynamic between 1975 and 2008.

\begin{tabular}{llcc}
\hline \multicolumn{1}{c}{ Metrics } & \multicolumn{1}{c}{ Description } & Unit & Threshold \\
\hline Total forest area & Area and percent of the landscape comprised by forest & ha/\% & Edge width (m): $0 \mathrm{~m}$ \\
\hline $\begin{array}{l}\text { Mean patch size/number } \\
\text { of patches }\end{array}$ & Mean size and total number of forest patches & ha/- & Edge width (m): $0 \mathrm{~m}$ \\
\hline Largest patch & $\begin{array}{l}\text { Area and percent of the forest cover comprised by the } \\
\text { largest patch }\end{array}$ & ha/\% & Edge width (m): $0 \mathrm{~m}$ \\
\hline Patch size distribution & $\begin{array}{l}\text { Number of fragments, area and percentage of forest } \\
\text { cover for different size classes }\end{array}$ & ha/\% & $\begin{array}{l}\text { Size classes (ha): }<1 \text { ha, } 1-10 \text { ha, } \\
\text { Edge width (m): } 0 \mathrm{~m}\end{array}$ \\
\hline Edge area & $\begin{array}{l}\text { Area and percentage of forest submitted to edge effects } \\
\text { for different edge widths }\end{array}$ & ha/\% & Edge width (m): 50, 100, 200,300 \\
\hline Connectivity (CONNECT) & $\begin{array}{l}\text { Proportion of functional joins between all forest } \\
\text { patches considering different distance }\end{array}$ & $\%$ & $\begin{array}{l}\text { Distance (m): } 75,100,300,500, \\
800,1000\end{array}$ \\
\hline $\begin{array}{l}\text { Mean proximity } \\
\text { (PROX_MN) }\end{array}$ & $\begin{array}{l}\text { Mean Euclidean distance among patches that are } \\
\text { within a specific search radius }\end{array}$ & - & $\begin{array}{l}\text { Search radius (m): } 75,100,300, \\
500,800,1000\end{array}$ \\
\hline
\end{tabular}

CONNECT: equals 0 when the landscape is composed of a single patch or none of the forest patches are connected; equals 100 when all patches are connected. PROX_MN: (unit less) increases as patches become closer and are more contiguous or less fragmented in distribution and vice versa. 


\subsection{Potential Impacts of Fragmentation}

Based on the results of the landscape structure analyses and assuming that the information extracted from the literature review (Tables 2-5) can be extended to the floodplain ecosystems, we inferred the potential impacts of forest fragmentation on the biodiversity of trees, birds, mammals and insects of the study area. Since the reviewed literature is not specific to the floodplain, it is important to highlight specific aspects related to this type of landscape. Unlike upland areas, floodplain landscape alternates between terrestrial and aquatic phases, since it is periodically inundated by lateral overflow of rivers and lakes. The flood-pulse [37] causes the biota to respond by morphological, anatomical, physiological, phenological and/or ethological (behavioral) adaptations [85]. For this reason, the floodplain has specific community structures, combining terrestrial and aquatic species, some of which are endemic while others are common to both floodplain and upland environments [85].

Given the complexity and specificities of floodplain environment, and the lack of specific studies of this ecosystem, the present research is restricted to the flooded forest habitat and species or functional groups related to this habitat. To this end, it is considered that adaptations of terrestrial organisms (forest dependent) to the flood pulse do not interfere in their susceptibility to forest fragmentation. Although the floodplain landscape has a certain degree of natural fragmentation due to the constant presence of water bodies (rivers and lakes), there is no evidence that floodplain forest species (plants and animals) have adapted to live in fragmented forests. Even though the floodplain forest has never been composed of a single patch covering the entire landscape, it is assumed that the amount and configuration (e.g., size, shape, and connectivity) of the original forest habitat allowed maintenance of high biodiversity and ecological processes [71,86,87]. Thus, it is also assumed that the increase in the fragmentation degree of the floodplain landscape will impact its biodiversity and ecological processes, similar to that occurring at the uplands.

Other important consideration is regarding annual floods and the degree of forest fragmentation, which are not related since the amount of forest cover and the configuration of forest fragments (e.g., size and shape) do not change with the increase of the water level. Annual floods can temporarily change the living area of many species in the floodplain, for example providing greater mobility to aquatic species and restricting the mobility of many terrestrial species in the landscape. This process, however, is temporary and is not related to the configuration of the forest habitat. For instance, many species with a large living area during the terrestrial phase can stay confined to a single tree during the aquatic phase (vertical migration), while others migrate to the uplands (horizontal migration), more remote areas (flying migration), or even stay submerged in active or dormant mode [85]. The fragmentation process addressed in this study is essentially related to anthropogenic factors, effective removal and fragmentation of forest habitat and permanent impacts on floodplain biodiversity and ecological processes.

\subsection{Environmental Perception of the Local Populations}

Given that the concept of ES implies benefits to humans, the biodiversity of floodplain forests should be understood as an ES only if it is being used or consumed or it benefits human populations in some way. Based on this assumption, we used the data on the environmental perception of riverine populations to assess whether the inferred impacts on biodiversity are perceived by the local populations through the endangerment of ES such as food, raw materials, medicine, biological control, pollination and nutrient cycling, which depend on the biodiversity of the studied groups. The collection of information in the field occurred between the 11 and 26 March 2014, when we visited 26 communities distributed throughout the study area (Figure 1). The interviews were collective (key informants), uniting the longest residing individuals with the greatest knowledge of the local flora and fauna of each community, such as leaders, fishers, farmers, hunters and healers. The process was done in the context of an informal conversation, with objective questions, but with the possibility of expanding on the theme. We used questionnaires specially created to gather the information of interest, which included not only questions about biodiversity, but also about other ES that are important 
to the riverine residents and dependent on the biodiversity of trees, birds, mammals and insects, such as food, raw materials, pollination, biological control, etc. Thus, the questionnaires contained questions about the possible alterations in the productivity of agricultural crops, incidence of pests, and occurrence of animal and plant species throughout recent decades. The questions referring to the occurrence of species were supplemented by a list of 23 animals and 72 plants species that are important to the riverine populations in terms of food, crafts, construction, fuel, the fabrication of utensils and medicinal products [88,89]. The interviewees were asked about the occurrence of each of these species in the region, their use, the possible fluctuations in terms of quantity in recent decades (scarcity/local extinction), in addition to the timing and likely reason of this fluctuation. A single questionnaire was applied per community, considering the responses in consensus among the group of respondents. Therefore, the data were evaluated at the community level and the results described in terms of percentage of communities that reported a given fact. The length of the interview varied depending upon the informants' interest and availability. The average session lasted about $40 \mathrm{~min}$ and all locals were very receptive and helpful.

It is important to point out that a number of researches have already used local population perception to complement or validate remote sensing land cover classification [90,91]. Perception information has been also successfully used to assess the driving forces of land cover changes and their location factors [91-93]. Those aspects, however, were not the focus of the present research of our research. Even so, the questionnaires included questions to assess population perception on the main drivers of floodplain forest fragmentation at present. The research was conducted according to national $[94,95]$ and international ethical guidelines. Only adult people were interviewed. All data gathered during population surveys were obtained with consent and analyzed anonymously. All respondents were informed about the nature of the research and signed a free consent term.

\section{Results}

\subsection{Dynamic of the Landscape}

The results of landscape dynamic show 70\% reduction of the forest habitat throughout the studied period (Figure 2). In 1975, the floodplain forests covered 30\% of the study area, equivalent to 281,403 ha. In 2008 , forest covered only $9.2 \%$ of the area, or 83,697 ha. The greatest alterations occurred in 1980-1987 and 1992-1997, with forest losses of 106,700 ha and 61,525 ha, respectively (Figure 3). These periods coincide with periods of increased production of jute and buffalo herds in the region, as it will be discussed in Section 5.

In relation to landscape fragmentation, there was a $79 \%$ increase in the number of forest fragments, accompanied by an $83 \%$ decrease of their average size, which fell from 236 ha to only 39 ha between 1975 and 2008 (Figure 3). In 1975, the area of the largest fragment on the landscape was 48,683 ha, covering $5.4 \%$ of the study area and representing $58.5 \%$ of the total forest area. By 2008 , the area of the largest patch diminished by $89 \%$ (5 ha), representing $0.6 \%$ of the study area and only $1.9 \%$ of the total forest area.

In both 1970 and 2008, most of the patches were $10-100$ ha (38\% and 35\% of the patches, respectively). In 1970, however, the patches larger than 1000 ha occupied a greater portion of the landscape, representing 77.6\% of the forest area (Figure 4). By 2008, the patches larger than 1000 ha represented only $1 \%$ of the forested area. In addition, there was a large increase $(600 \%)$ in the number of patches smaller than 100 ha, which represented only 7\% of the forest area in 1970, but 49\% in 2008 . 

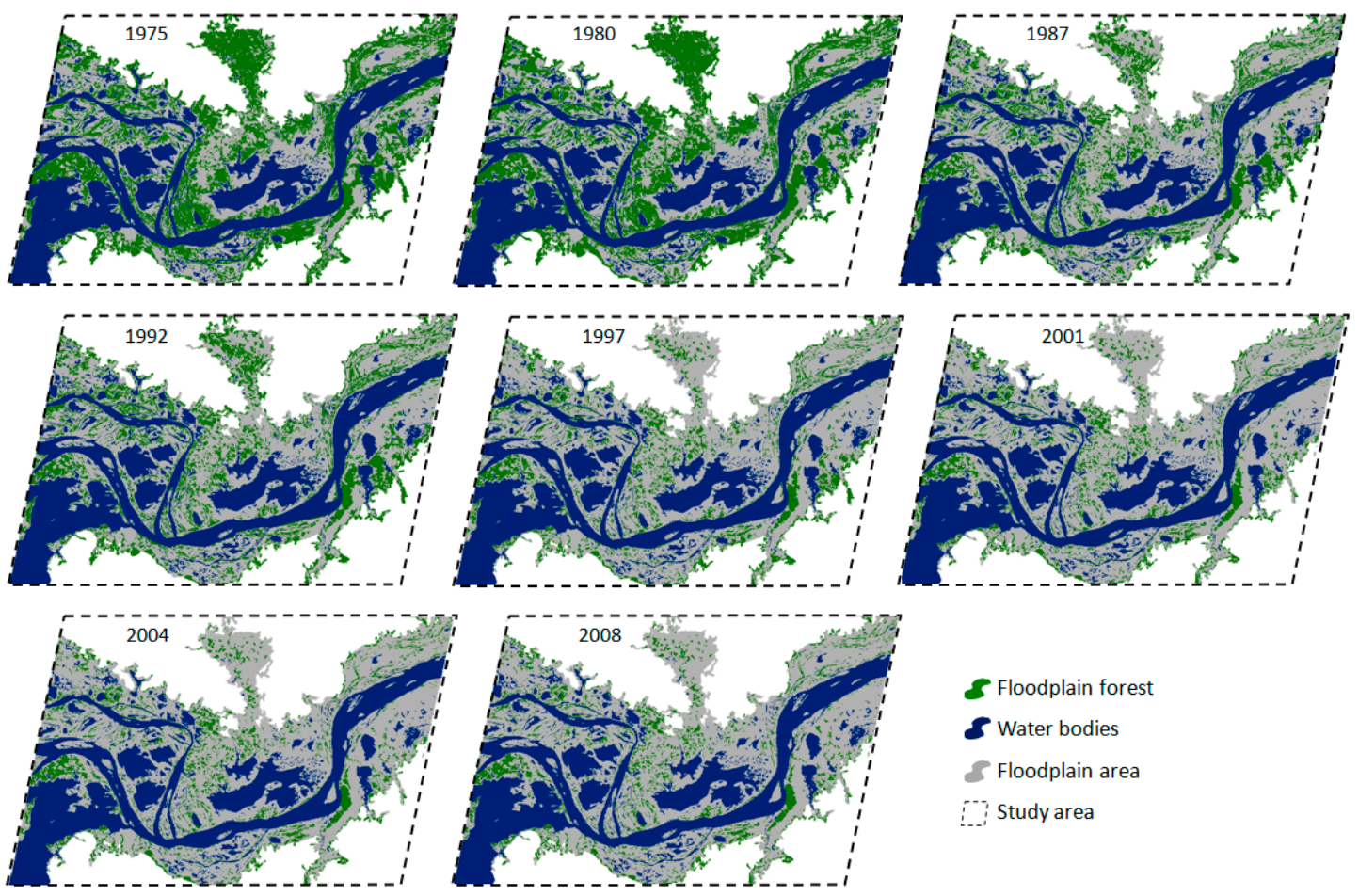

Figure 2. Maps of the floodplain forest cover for the study area between 1975 and 2008.
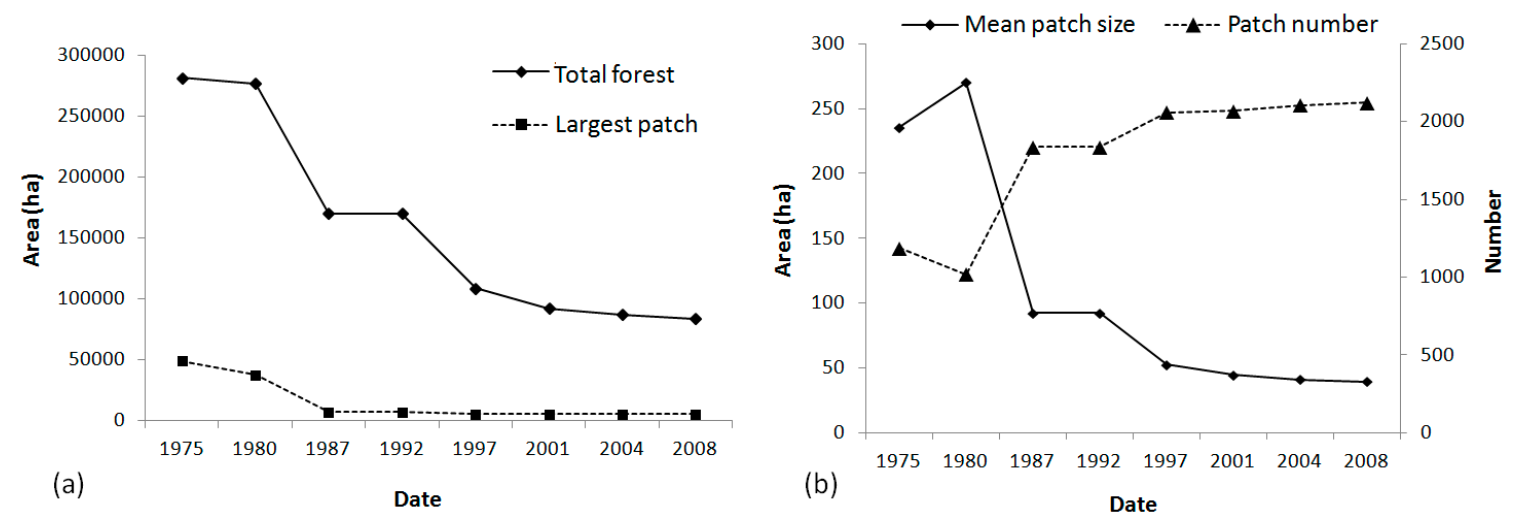

Figure 3. Evolution of the forest cover between 1975 and 2008: (a) total forest area and largest forest patch area; and (b) number and average size of the forest patches.
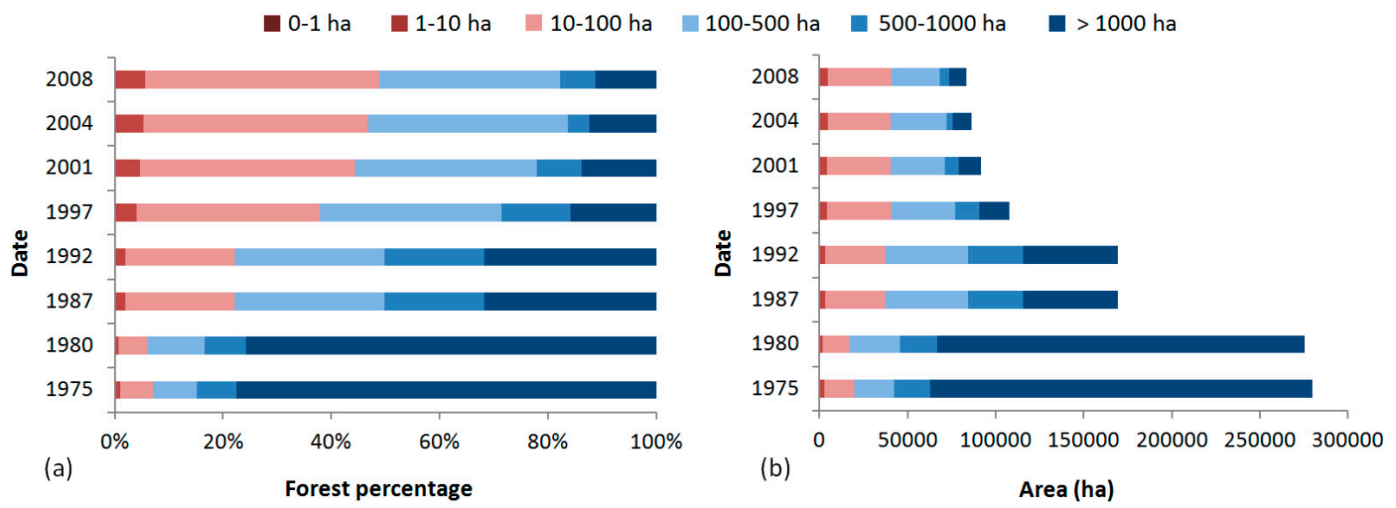

Figure 4. Distribution of the patches among six size classes and its evolution between 1975 and 2008: (a) percentage forest cover; and (b) area in hectares. 
Inherent to the process of fragmentation is the creation of new forest edges. In fact, the results show a remarkable increase in edge areas throughout the studied period, even considering different widths (Figure 5b). Due to the large reduction of forest cover, the increase of edge areas is given only in relation to the percentage of forest and not in absolute terms (forest area). In 1975, the edges represented between $22 \%$ and $70 \%$ of the forest area, depending on the width considered $(50 \mathrm{~m}, 100 \mathrm{~m}$, $200 \mathrm{~m}$ or $300 \mathrm{~m}$ ), coming to represent between $42 \%$ and $92 \%$ of the forest area in 2008 (Figure $5 \mathrm{a}$ ). Consequently, there was a reduction in the core area of patches throughout the period (Figure 5b). This decrease was in relation to both the percentage of forest as well as the total area in hectares and independent from the width considered. In 1975, the core of the patches occupied between 217,695 ha and $84,046 \mathrm{ha}$, depending on the selected edge width ( $50 \mathrm{~m}$ to $300 \mathrm{~m}$ ), and occupied between 47,829 ha and 6916 ha in 2008. If we consider a 100-m edge (most frequently used in the literature), the area of effective habitat (core area) for species in 2008 corresponded to only $34 \%$ of the forest total. For 300-m edges, the area of effective habitat fell to only $8 \%$ of the total forest area, which represents only $0.8 \%$ of the study area.

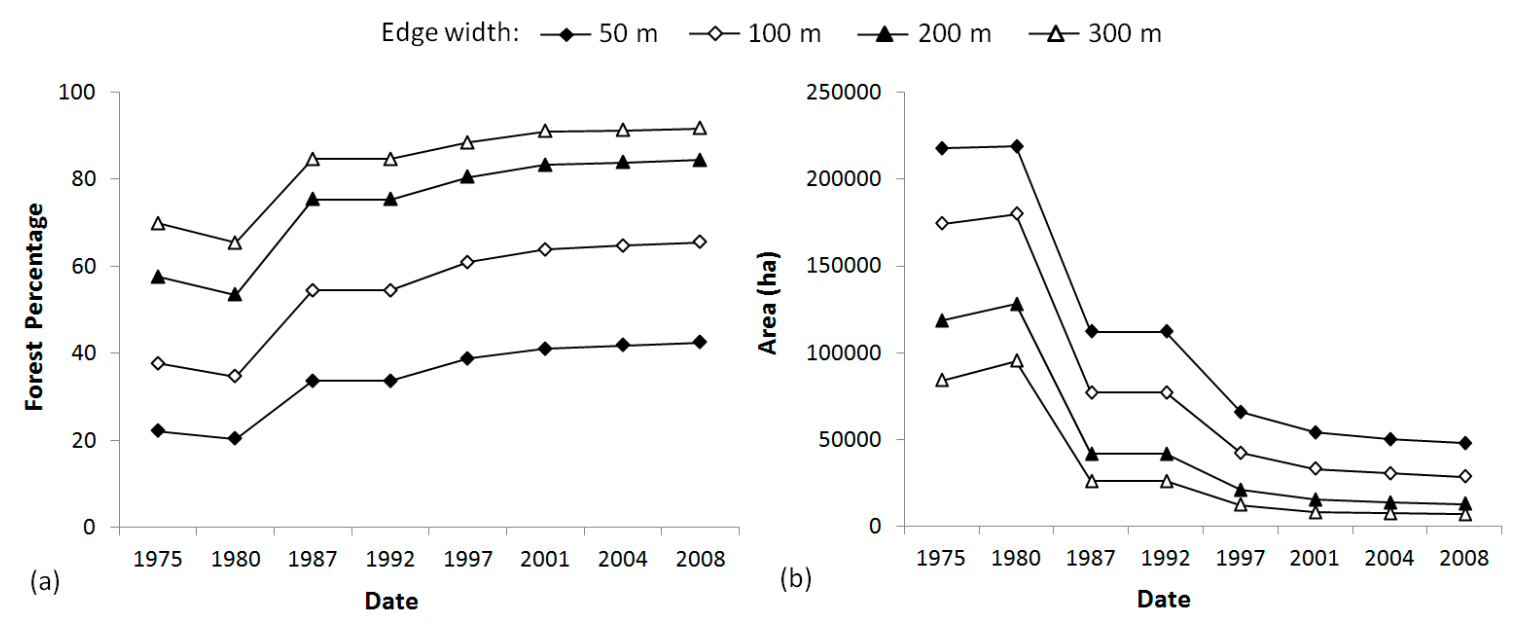

Figure 5. Evolution of edge and core forest area between 1975 and 2008: (a) proportion of edge area; and (b) extension of core area.

In relation to the connectivity/isolation of the patches, significant alterations over the long term have also been observed. The results show that patch connectivity (CONNECT) decreased by an average of $63 \%$ between 1975 and 2008. Considering different functional distances $(75 \mathrm{~m}, 100 \mathrm{~m}$, $300 \mathrm{~m}, 500 \mathrm{~m}, 800 \mathrm{~m}$, and $1 \mathrm{~km}$ ), this reduction varied from $76 \%$ to $50 \%$ (Figure 6a). The value of this index is close to zero when the patches are functionally connected. This indicates that, in 1975, patch connectivity was already low, not exceeding $0.4 \%$. In fact, the period of greatest expansion of jute cultivation in the region occurred between 1950 and 1975, suggesting that the forest fragmentation in this period was greater still than in the study period (1975-2008). It is important to highlight, however, that when considering the floodplain landscape, with its large proportion of water bodies (34\%), forest patch connectivity would never reach $100 \%$. In this case, the temporal difference of connectivity values is more important than the value of the metric itself, given that the maximum value of connectivity that is possible for the region is unknown. The mean proximity (PROX_MN) presented even greater alterations throughout the period, with a decrease of more than $99 \%$ for all the search radii (Figure $6 \mathrm{~b}$ ). The majority of the alteration occurred between 1975 and 2001, with a large fall in 1980-1987. This last period coincides with the greatest loss of forest cover and the greatest increase in edge areas. 


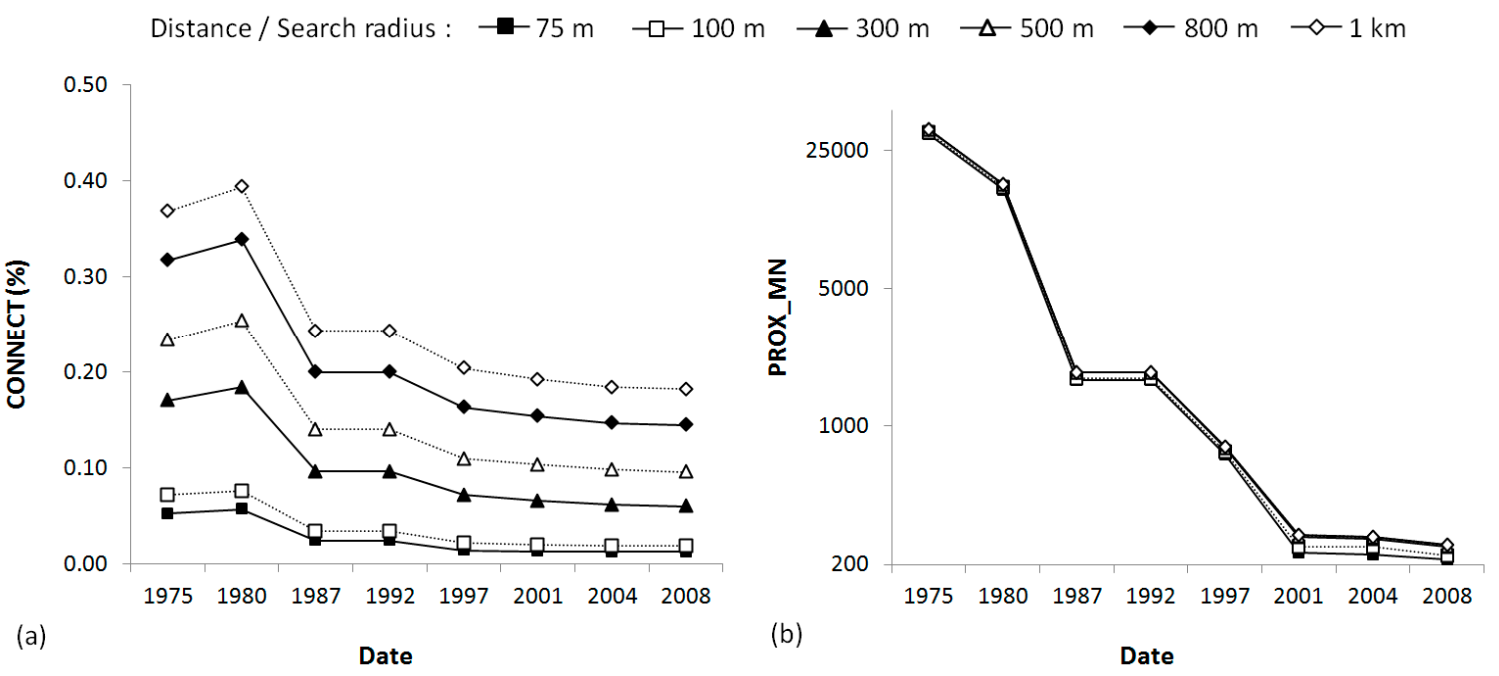

Figure 6. Evolution of forest patch connectivity and isolation between 1975 and 2008: (a) connectivity index (CONNECT); and (b) mean proximity index (PROX_MN).

\subsection{Fragmentation and Biodiversity}

Based on the results of landscape dynamics and assuming that the information extracted from the literature can be extended to the floodplain ecosystems, inferences were made in terms of the probable impacts of floodplain forest fragmentation on the biodiversity of the groups addressed in this study.

\subsubsection{Biodiversity of Trees}

The tree communities play a key role in forest ecosystems, being responsible for the forest structure, the regulation of microclimate conditions [41], carbon storage and the production of essential trophic resources for a wide variety of organisms including man [96]. According to the literature review, the landscape alterations that most negatively influence tree biodiversity are the reduction of patch size and the increase in edge areas, followed by the loss of connectivity and the isolation time of the patches (Table 2).

Two classes of patch size appear to affect tree communities: the patches $\leq 100$ ha and the patches $\leq 2$ ha. The latter presents effects even more severe than the former, mainly due to the large increase in the abundance of pioneer species ( $>400 \%$ ) and in the rates of species mortality, damage and turnover $(>300 \%)[41,42,44]$. Fortunately, throughout the analyzed period, less than $1 \%$ of the forest cover suffered the severe effects of area ( $\leq 2 \mathrm{ha}$ ) on the tree communities (Figure 7a). Despite this, the area of the patches $\leq 2$ ha increased by $49 \%$ (Figure $7 \mathrm{~b}$ ), which inspires consternation regarding the degree of impact that these patches have on the tree communities. Figure 7a shows the temporal variability of area covered by patches $\leq 2$ ha, which indicate that between 1975 and 1980 forest areas $>2$ ha were fragmented into patches $\leq 2$ ha. Between 1980 and 1987, many of these patches ( $\leq 2$ ha) were probably removed (deforested); and from 1997 to 2001 new forest areas $>2$ ha were fragmented into patches $\leq 2$ ha.

More worrisome, however, is the spread of patches of 2-100 ha in size, which represented only $7 \%$ of the forest cover in 1975, but $49 \%$ in 2008 (Figure 7). The tree communities in patches of this size class suffer large impacts, including a 50\% increase in the rates of species mortality, damage and turnover, greater abundance of pioneers and a $20 \%$ reduction in functional and species diversity [39,41,42]. 


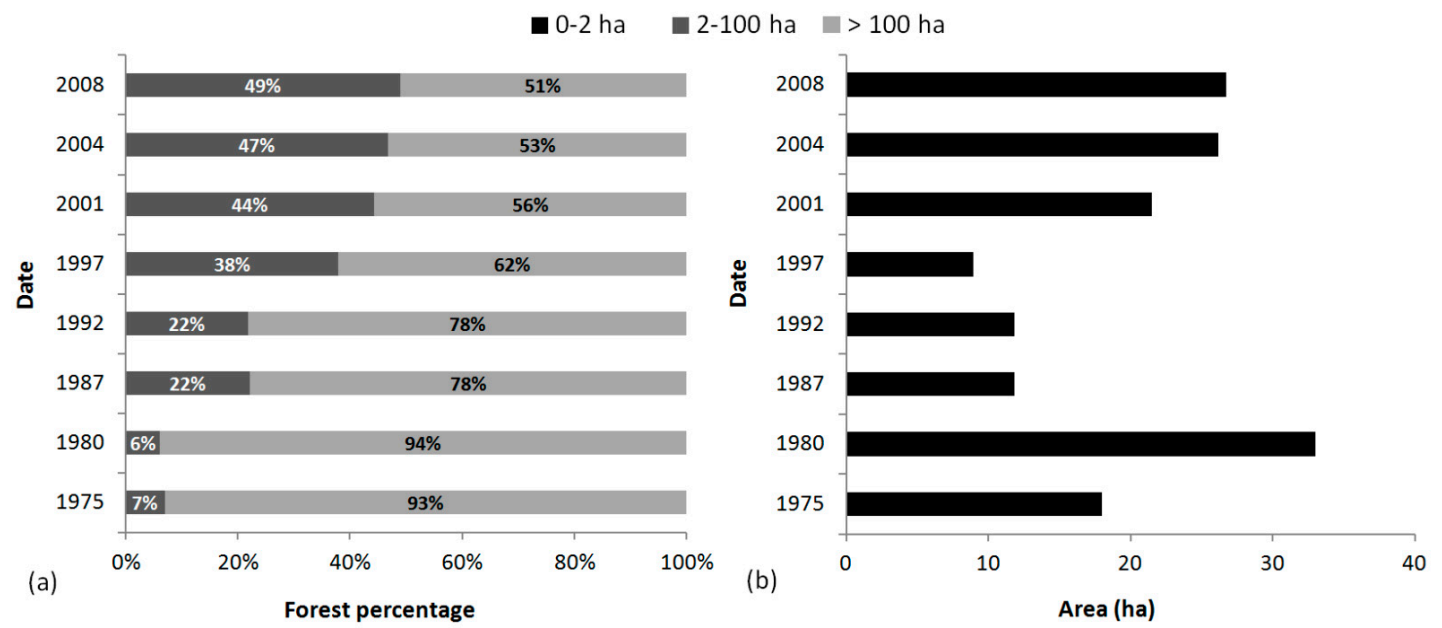

Figure 7. Distribution of the patches among three size classes and its evolution between 1975 and 2008:

(a) percentage forest cover; and (b) area in hectares for patches of 0-2 ha.

In relation to edge areas, the most significant impacts on the tree communities are apparent within the first $300 \mathrm{~m}$ of edge. This area can be divided into three width classes according to the degree of impact: $\leq 50 \mathrm{~m}, 50-100 \mathrm{~m}$, and 100-300 m. The data from this study (Figure 8) show that, since the $1970 \mathrm{~s}$, most of the forest cover $(70 \%)$ was susceptible to the impacts of edges with widths of $0-300 \mathrm{~m}$. These impacts include increased rates of species mortality, damage and turnover, higher incidence of canopy gaps and greater abundance of pioneers. In 2008, this scenario worsened, with almost half $(43 \%)$ of the forest area becoming susceptible to the most severe effects $(0-50 \mathrm{~m})$, and only $8 \%$ of the forest cover was found to be free from edge effects $(>300 \mathrm{~m})$.

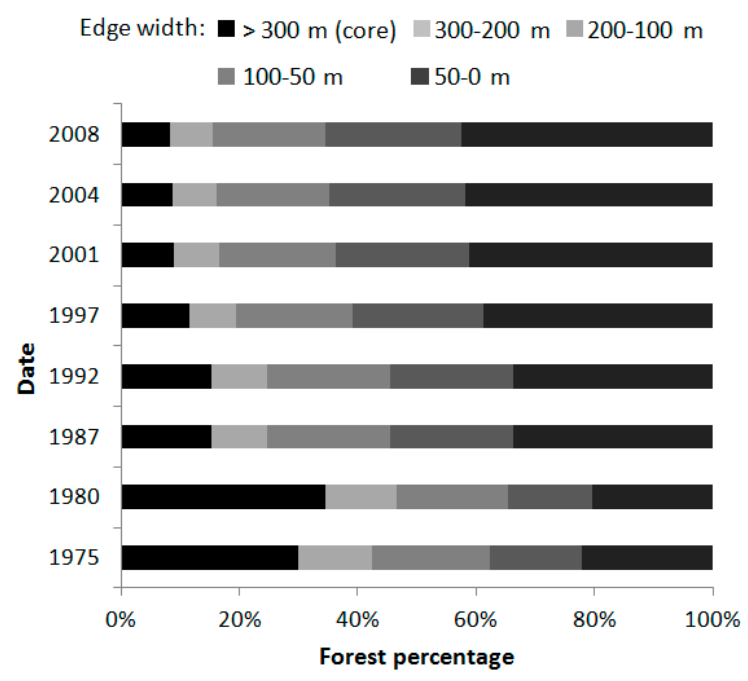

Figure 8. Distribution of the edge areas among width classes and its evolution between 1975 and 2008.

Other factors that affect tree communities are the degree of connectivity and the isolation time of the patches on the landscape. Generally, the greater the distance and isolation time, the greater are the impacts on tree richness and diversity in the forest patches. After 14-20 years of isolation, the forest patches present greater density of pioneer species, reduction in late successional species, less phylogenetic dispersion and less genera richness than before fragmentation [44,45]. The data of this study show that the degree of landscape fragmentation increased from 1987 onward, indicating that the majority of patches must have been isolated during the preceding 12 years. In 1975, there were 1187 patches; between 1975 and 1987, 650 new patches appeared, and between 1987 and 2008, another 
286 emerged (Figure 3b). This indicates that $87 \%$ of the patches might have been created by 1987, suffering, therefore, the negative effects of more than 20 years of isolation.

\subsubsection{Biodiversity of Birds}

Birds are important components of forest ecosystems, and alterations in these communities can affect multiple trophic levels and different ES $[97,98]$. Following the literature review, the landscape alterations that most affect the biodiversity of birds are the reduction of patch size and the loss of connectivity between patches, followed by the increase in edge areas (Table 3).

In general, patch size is positively related to bird diversity and, therefore, the smaller the patch, the lower the diversity. The one-hectare patches are the most affected, followed by 10-hectare and 100-hectare patches, sequentially. In this sense, the most worrisome alterations in the study area are related to the increase of 10- and 100-hectare patches, since the one-hectare patches represent less than $1 \%$ of the forest cover. Between 1975 and 2008, the patches of 100 ha (10-100) increased by $111 \%$ in terms of forest cover area and by $610 \%$ in terms of proportion (Figure 4 ). The same happened for patches of 10 ha (1-10), which increased by $79 \%$ and $500 \%$ in terms of area and proportion, respectively (Figure 4). The abundance of birds is strongly affected in patches of this scale (100 ha and $10 \mathrm{ha}$ ), reaching $28 \%$ and $71 \%$ less abundance than in areas of continuous forest [49-52]. In 2008, $49 \%$ of the study area's forest cover was susceptible to these impacts (Figure 4).

In relation to connectivity, the distance between patches that affects mobility of birds on the landscape varies from almost zero to $425 \mathrm{~m}$, depending on the species. In general, the number of species capable of traveling over open areas decreases as the distance between patches increases, and this affects the diversity of bird in isolated patches. In the Amazon, an isolation of more than $400 \mathrm{~m}$ between patches has the potential to block up to $100 \%$ of the movement of forest dependent birds over the landscape, reducing richness by $30 \%$ and strongly affecting $(30 \%-100 \%)$ species abundance in the patches $[47,51]$.

The results of this research show that forest patch isolation increased substantially during the study period (Figure 6). In 1975, the value of the connectivity index (CONNECT) for a functional distance of $500 \mathrm{~m}$ was already low (0.233), reaching close to zero (0.096) in 2008 (Figure 6a). This indicates that, in 2008, most of the patches in the landscape were $500 \mathrm{~m}$ apart from each other, as the index tends toward zero when no patch is found to be functionally connected. Therefore, the movement of birds across the landscape-and, consequently, their diversity—is highly compromised, with the risk of local extinction in most of the patches. It is also estimated that the abundance of understory birds is strongly affected in the first $50 \mathrm{~m}$ of edge $[42,46]$. This points to serious impacts on bird abundance in the study area, since the proportion of 0 - to 50 -m edges increased by $91 \%$ during the study period, representing $42 \%$ of the forest cover in 2008 (Figure 5).

\subsubsection{Biodiversity of Mammals}

Mammals play an important role in ecosystems, acting on different trophic levels (herbivores, omnivores and predators), and as pollinators, seed dispersers, and pest and disease regulators and as indicators of general ecosystem health [99]. Mammals also constitute an important source of food for the local human populations and are considered important elements of the local culture, which uses the skins, bones and teeth for a variety of purposes [89]. This group, however, appears to be one of the most affected by forest fragmentation, particularly medium- and large-sized mammals, which, due to their body mass, have specific requirements in terms of home range, food, shelter and reproduction $[100,101]$. The landscape parameters most related to variations in mammal diversity are patch size, edge areas and isolation (Table 4).

It is estimated that $90 \%$ of the variation in mammal richness is explained by patch size, with patches $\leq 100$ ha being the most affected [55]. These patches exhibit a reduction in mammal richness $(>80 \%)$, particularly for sensitive, large-sized species $(\sim 100 \%)$ that are common in floodplain areas, such as jaguars, otters, ungulates (e.g., tapir, peccary, red brocket, and gray brocket) and large 
xenarthra (e.g., giant anteater, and giant armadillo). For this reason, Michalski and Peres [55] highlight the importance of large forest patches $(>10,000 \mathrm{ha}$ ) to maximize the persistence and maintenance of species abundance in tropical areas.

The data of this study suggest increasing pressure on the mammal communities in recent decades, given the reduction of patches $>100$ ha $(84 \%)$ and of the total loss of patches $>10,000$ ha. Between 1975 and 2008, the area of the largest patch on the landscape fell from 48,683 ha to only 5212 ha (Figure 3a), and the area occupied by patches $>100$ ha fell from 260,035 ha to 42,492 ha (Figure 4). In 2008, there were no patches large enough to guarantee the persistence and maintenance of mammal abundance on the landscape (>10,000 ha). Furthermore, 49\% of the forest cover (Figure 4 ) was composed of patches $<100$ ha and were therefore susceptible to strong impacts on mammal richness, including the risk of local extinction.

In relation to edge area, it is calculated that $83 \%$ of abundance and $74 \%$ of mammal richness are explained by this parameter [56]. The most significant impacts are felt in the first $180 \mathrm{~m}$ of edge, which exhibit up to $94 \%$ less abundance and $78 \%$ less richness than the forest interior [57]. In the study area, edges of $0-200 \mathrm{~m}$ represented $57 \%$ of the forest cover in 1975 and more than $84 \%$ in 2008 (Figure 8), which indicates that mammal diversity could be already compromised in 1975, worsening further in 2008.

Another critical factor concerns the degree of patch isolation in the study area and the potential impacts on mammal communities, such as a 50\% reduction in richness at distance greater that $300 \mathrm{~m}$ [53]. In 2008, patch connectivity at this distance (300 m) was close to zero (0.0598), indicating that the richness of mammals on the landscape may be compromised.

\subsubsection{Biodiversity of Insects}

The biodiversity of insects influences ecosystem dynamics as an intermediary of numerous mechanisms such as leaf litter decomposition, pollination, biological control, plant growth suppression, as well as serving as prey for other species [102]. This is because many groups are able to cause physical changes in the environment and alter the availability of resources for other species such as pollinator insects (e.g., bees, and butterflies), parasitoids (e.g., wasps, and flies), decomposers (e.g., beetles, and caterpillars), herbivores and seed predators (e.g., beetles, ants, and caterpillars) [62].

Forest fragmentation has diverse effects on insect communities. In general, pollinator, decomposer and parasitoid insects (herbivore insect parasites) are affected negatively, while the herbivores and seed predators are favored in terms of abundance and disadvantaged in terms of species richness. According to the literature review, the landscape alterations that most effect insect communities are habitat loss, patch size, edge area and patch isolation (Table 5).

The loss of more than $70 \%$ of forest habitat can strongly affect the richness of Meliponini bees and causes irreversible alterations in the species composition of butterflies [60,70]. Meliponini bees are responsible for the pollination of around 90\% of the flowering plants in the Amazon [103,104], and contribute strongly to the increase of agricultural production and to the regeneration process of natural vegetation [105]. The butterflies act as pollinators, defoliators, decomposers, prey and hosts, and their diversity is related to nutrient recycling, plant population dynamics, and the predator-prey relationship of an ecosystem [106,107].

In the study area, the integrity of these groups and their services is cause for concern due to the loss of $70 \%$ of the habitat during the studied period, and only $9 \%$ on the study area was forested in 2008. Even discounting the area permanently covered by water during the period $(328,800 \mathrm{ha})$, the floodplain forest cover comprised only 14\% of the study area in 2008.

The patch area also directly affects insect communities, particularly in patches $\leq 10$ ha, where the rate of parasitism is $50 \%-100 \%$ lower than in control areas, depending on the insect species considered [68]. This occurs due to the decrease in richness of parasitoid insects, which are most sensitive to fragmentation. In one-hectare patches, the impacts on parasitoid richness can reach $80 \%$ [68]. These changes imply a decline in the natural biological control of herbivore insects, increasing 
the rates of herbivory and the likelihood of the emergence of forest and agricultural pests [28]. The data of this study show that the patches most susceptible to these impacts ( $\leq 10$ ha) increased by $79 \%$ in area and by more than $500 \%$ in proportion of forest cover. In 1975, the patches $\leq 10$ ha represented less than $1 \%$ of the forest cover, increasing to $5.6 \%$ by 2008 (Figure 4 ).

In relation to edge area, the most significant impacts on the insect communities are felt within the first $300 \mathrm{~m}$. This area can be divided into four width classes according to the degree of impact: $\leq 50 \mathrm{~m}$, $\leq 100 \mathrm{~m}, \leq 200 \mathrm{~m}$, and $\leq 300 \mathrm{~m}$. These impacts include increased rates of invasion and herbivory, greater abundance of herbivores, lower rates of parasitism and reduced diversity of pollinators [42,48,62-64,69]. In $1975,30 \%$ of the forest cover was free from edge effects on the insect communities (>300 m). In 2008, however, this situation worsened considerably, given that only $8 \%$ of the forest cover was found to be free of edge effects (Figure 8). Furthermore, there was a large increase $(43 \%)$ in areas susceptible to the most severe effects $(\leq 50 \mathrm{~m})$, which came to represent almost half $(42 \%)$ of the forest cover in 2008 (Figure 8).

Another factor that negatively affects the insect community is increasing isolation between forest patches. The distance between patches that affects the dispersal of insects varies between $50 \mathrm{~m}$ and $1 \mathrm{~km}$, and it effects include decreased richness of herbivores and parasitoids, lower rates of parasitism and mortality of hosts, and less richness and visitation of pollinators [28,60,66,67]. As previously discussed, the degree of patch isolation on the landscape is worrisome, independent of the functional distance considered. Even the greatest functional distance and search radius $(1 \mathrm{~km})$ exhibits a $50 \%$ reduction in connectivity (CONNECT) and more than a 99\% reduction in mean proximity (PROX_MN) of the patches between 1975 and 2008 (Figure 6). In 2008, the value of the connectivity index for the distance of $1 \mathrm{~km}$ was only 0.182 , reaching 0.013 for a functional distance of $75 \mathrm{~m}$ (Figure 6a). These values indicate that patch connectivity and, consequently, the insect groups and their related processes are greatly compromised.

\subsection{Environmental Perception of Riverine Populations}

The analysis of the environmental perception data shows that $96 \%$ of the visited communities report some type of alteration in local flora. The alterations cited by the interviewees were forest cover loss $(88 \%)$ and decreased abundance and/or variety of trees and other plants (22\%). According to them, the main reasons for these alterations are the forest removal for the establishment of plantations $(40 \%)$ and the creation of pastures (30\%), followed by selective logging and extreme floods ( $15 \%$ each). This last one is related to the increase in time and/or amplitude of the annual regular floods, caused primarily by global climate changes but also by forest cover removal at the local level $[13,108,109]$. More than half of the interviewees (56\%) report that the alterations occurred approximately 30 years earlier, i.e., around 1984, given the date of the interviews (2014). This information agrees with the results of the landscape dynamics, which show that the greatest habitat losses and forest fragmentation occurred between 1980 and 1987 (Figures 3 and 5).

In relation to the use and importance of flora by and for the local communities, $100 \%$ of them attribute maximum importance to this resource, particularly for medicinal use (96\%), household consumption $(92 \%)$, commercialization $(81 \%)$, civil construction $(65 \%)$ and the fabrication of artifacts $(42 \%)$. Of the 72 plant species listed in the questionnaire, an average of $46 \%$ of them were recognized as present in the region and utilized in some form by the riverine residents. However, the species recognized by the residents varied widely $(19 \%-75 \%)$ according to the community sampled. The likely causes of this and other variations in responses among the visited communities are local factors such as the distance to urban centers, the type of landscape unit where the community is inserted (island or levee, lake or river edge), landscape structure in the community surrounding, etc.

Only the plant species recognized by the residents in each community were considered. On average, $14 \%$ of them were cited as scarce or extinct in recent decades. Among the most frequently cited species are: Theobroma cacau (cacao), Lecointea amazonica (pracuuba), Hevea brasiliensis (rubber tree, seringa) and Calycophyllum spruceanum (capirona, pau-mulato); all of these tree species are native to the 
region. In general, the main reasons for the scarcity/extinction of plant species are the extreme floods $(38 \%)$, overexploitation (25\%) and deforestation (21\%). In relation to the time of scarcity, more than half (55\%) of the reports cite 20 to 30 years ( 1994 to 1974), while 19\% cite 20 years ( 1994), 17\% cite 30 years $(\sim 1984)$ and 18\% cite 40 years ( 1974). However, it is important to note that both, the reason and the time of scarcity/extinction vary according to species. For L. amazonica and C. spruceanum, for example, the most cited reason is overexploitation of the species, while for T. cacau and H. brasiliensis the main reasons are the extreme floods and deforestation. Furthermore, the time of scarcity/extinction most reported per species is 30-40 years for T. cacau, 30 years for H. brasiliensis, 20 years for L. amazonica and 50 years for C. spruceanum.

The scarcity of these and other plant species cited in the interviews has direct impacts on the well-being of the riverine population, since the plants are used for various purposes. Sixty-eight percent of the communities report the use of $T$. cacau as a food and $42 \%$ said that $H$. brasiliensis is used to extract rubber and make artifacts. In relation to L. amazonica, its main uses are for construction (35\%), the fabrication of artifacts (27\%), fire wood (12\%) and as a medicinal product $(3.8 \%)$. C. spruceanum is mainly used as fire wood (73\%), for construction (19\%) and as a medicinal product (19\%).

In relation to the local fauna, $100 \%$ of the visited communities reported a decrease in the quantity and/or variety of the resource in recent decades, particularly of fish (100\%) and game animals (62\%), which include mammals, birds and reptiles. According to the interviewees, the main reason for these alterations in local fauna is overexploitation (92\%) due to the increase in population and the resource extraction by non-local migrants, followed by deforestation $(12 \%)$ for the creation of plantation and pastures. A large majority of the interviewees (73\%) reported that the alterations occurred around 1984 (30 years previous, 2014 based year). With respect to the use and importance of these resources by and for the riverine residents, $96 \%$ of the visited communities attribute the maximum value of importance to the fauna, with the main uses of the resource being domestic consumption (100\%), commercialization (81\%), medicinal use (77\%) and the fabrication of artifacts (23\%). Of the 23 animal species listed in the questionnaire (seven birds, ten mammals and six reptiles), an average of $71 \%$ $(35 \%-100 \%)$ of them were recognized as being present in the region $(92 \%$ of the birds, $47 \%$ of the mammals and $84 \%$ of the reptiles).

In relation to the scarce/extinct species of each group, an average of $11 \%$ of the birds, $29 \%$ of mammals and $19 \%$ of the reptiles were cited by the communities (considering only species recognized by the residents in each community). The species most cited as scarce/extinct were Mycteria americana (wood stork, passarão) for birds; Trichechus inunguis (amazonian manatee, peixe-boi), Hydrochoerus hydrochaeris (capybara) and Agouti paca (paca) for mammals; and the turtles Podocnemis unifilis (yellow spotted river turtle, tracajá), Podocnemis expansa (arrau turtle, tartaruga-da-amazônia) and Podocnemis sextuberculata (six-tubercled amazon river turtle, pitiu) for the reptiles. According to the interviewees, the main reason for the scarcity/extinction of the animal species is increased hunting (63\% of reports) in the last 20 to 30 years $(22 \%$ and $17 \%$ of reports, respectively). In fact, habitat fragmentation facilitates hunting by allowing greater access to forest areas that were inaccessible prior to fragmentation, as well as leaving animals more exposed and close to the population. The same is true for other overexploitation activities [110,111].

Many animal species cited as scarce/extinct constitute important sources of food and medicine for the riverine residents. The species that $100 \%$ of the communities reported consuming as food include T. inunguis, P. unifilis, P. expansa and P. sextuberculata. Furthermore, $17 \%$ of the communities reported eating $M$. americana, $85 \%$ for $H$. hydrochaeris and $31 \%$ for A. paca. The species T. inunguis and $H$. hydrochaeris were also cited as sources of medicinal products by $31 \%$ and $7.7 \%$ of the visited communities, respectively.

The data presented in this section indicate that the biodiversity of trees, birds and mammals of the region are greatly compromised, and the effects have been felt by the local populations throughout recent decades, particularly in the last 30 years. Among these effects, we can cite scarcity and local extinction of the animal and plant species due primarily to the overexploitation of natural resources. 
As mentioned before, one of the deleterious effects of fragmentation is increased anthropogenic pressure caused by the facilitation of access to ecosystem resources that were inaccessible prior to fragmentation [110,111].

The field data also show possible impacts on insect communities in the region. According to the riverine residents, the last 30 years have seen an increase in the incidence of pests and a decrease of agricultural productivity, which was reported by $19 \%$ (pests) and $46 \%$ (productivity) of the communities. These factors are related to the alterations in the communities of organisms, including insects, birds and mammals, that are responsible for natural biological control, pollination and nutrient cycling in the soil. Family agriculture is practiced by $85 \%$ of the visited communities and, according to $50 \%$ of the visited communities, many crops that were abundantly productive in the past have become almost barren due to pest attacks, possible lack of pollination (lack of fruiting) and loss of soil fertility.

In this context, the field information corroborates the inferences made regarding the impacts of fragmentation on biodiversity and other ES crucial to the local populations, such as food (hunting, and fruit), fire wood (energy), raw material (construction of shelter, boats and artifacts), medicines (plants and animals), natural biological control, pollination and nutrient cycling.

\section{Discussion}

Our approach for temporal mapping of forest cover including field data and information based on population interviews (Section 3.3) provided the necessary accuracy for a sound computation of the landscape metrics. Forest cover changes as depicted by Landsat time series were largely corroborated by previous studies based on field observations, socio-economic analyses and population perception. Time changes on total forest cover and on landscape metrics are explained by the successive economic cycles of the Amazon floodplain. According to Winklerprins [18], jute production was a major driver of floodplain deforestation, but the loss of jute market in the 1960s gave space for crop abandonment followed for forest regrowth. The author, however, points out that despite the general trend of diminishing jute production as of 1965, there were two peaks of significant increase in production between 1980 and 1987, more specifically in 1982 and 1986. Conversely, the period between 1975 and 1980 was marked by an accentuated decline in jute production [18], corroborating the data of this study, which show relative stability of the forest cover during this period. As of 1986, there was a large decrease in jute production, and buffalo ranching came to play a more important economic role in the region. Data on buffalo herds between 1975 and 2008 show that the greatest increase in the region occurred between 1990 and 1995 [96], coinciding with the second period of intense forest habitat loss (1992-1997). The use of data from the interviews also helped to validate and complement the remote sensing data analyses. It is important to point out, however, that the use of local population perception for complimenting and/or validating remote sensing land cover maps is not new.

A number of researches have already used local population perception for complement or validate remote sensing land cover classification. Ariti et al. [90] have used surveys complemented with field observations and remote sensing data to study the perception and the adaptation strategies to land cover changes in Ethiopia by comparing perceived and observed changes. The study showed that population perceptions in relation to land cover change trends have corresponded to those provided by remote sensing data. According to the authors, the use of older respondents to gather information on historical land use have guaranteed an accurate rendition of the land use change as depicted from the interpretation of time series of remote sensing images. A similar approach has already been applied by Renó et al. [17] for mapping deforestation of flooded forest in a reach of the Amazon River floodplain, where the inclusion of old respondents was combined with botanical observations in order to validate recent and ancient maps and get information about the likely causes of deforestation. Tasser et al. [91] have also interviewed farmers to validate historical maps derived from aerial photography and understand the process of natural reforestation of Eastern Central Alps.

In the present study, the maps derived from time series of remotes sensing image were applied not only to assess land cover changes but also for computing landscape metrics related to ES services 
provision. As mentioned earlier, the selection of metrics was based on literature review about the impact of forest fragmentation on ecological groups relevant to the floodplain population (Table 1). The lack of studies carried out specifically on floodplain forests is a potential limitation of using literature to infer the relationship between landscape metrics and impacts of fragmentation on ES. The assumption that the metrics could be extended to floodplain so as to infer the biodiversity of trees, birds, mammals and insects of the study area is a source of uncertainty since the floodplain biota has a series of adaptations to the flood-pulse $[37,85]$. However, these adaptations do not interfere in the biota (forest dependent) susceptibility to forest fragmentation. Although the floodplain is a naturally fragmented environmental, the original forest habitat allowed maintenance of high biodiversity and ecological processes $[71,86,87]$. Thus, it is considered that the increase in the fragmentation degree of the floodplain landscape will impact its biodiversity and ecological processes similarly to that occurring at the uplands.

Besides, the use of perception data of the riverine populations helped to validate the inferences about the impacts of fragmentation on ES provided by the biodiversity of selected groups and (food, raw materials, medicine, biological control, pollination and nutrient cycling). Actually, the analyses of the results of the population perception data have corroborated all the inferences. As shown in Table 7, most of the respondents were able to identify not only the main impacts on ES, but also the time frame when the changes occurred and some of the driving forces responsible for floodplain forest fragmentation (agriculture and cattle rising). This last aspects, however, was not the focus of the present research, and other studies have addressed more properly the issue, using local population perception to identify the driving forces of land cover changes and also their location factors $[92,93]$.

Table 7. Main results of environmental perceptions of the riverine population.

\begin{tabular}{|c|c|}
\hline Environmental Perception & Visited Communities \\
\hline \multicolumn{2}{|l|}{ Flora } \\
\hline Reports of alterations & $96 \%$ \\
\hline $\begin{array}{l}\text { Types of alteration: } \\
\text { Forest cover loss } \\
\downarrow \text { abundance/variety }\end{array}$ & $\begin{array}{l}88 \% \\
22 \%\end{array}$ \\
\hline $\begin{array}{l}\text { Reasons for alterations: } \\
\text { Deforestation (plantations) } \\
\text { Deforestation (pasture) } \\
\text { Selective logging } \\
\text { Extreme floods }\end{array}$ & $\begin{array}{l}40 \% \\
30 \% \\
15 \% \\
15 \%\end{array}$ \\
\hline $\begin{array}{l}\text { Most reported period: } \\
\sim 1984\end{array}$ & $56 \%$ \\
\hline \multicolumn{2}{|l|}{ Fauna } \\
\hline Reports of alterations & $100 \%$ \\
\hline $\begin{array}{l}\text { Types of alteration: } \\
\downarrow \text { abundance/variety (fish) } \\
\downarrow \text { abundance/variety (game animals) }\end{array}$ & $\begin{array}{c}100 \% \\
62 \%\end{array}$ \\
\hline $\begin{array}{l}\text { Reasons for alterations: } \\
\text { Overexploitation } \\
\text { Deforestation (plantation/pasture) }\end{array}$ & $\begin{array}{l}92 \% \\
12 \%\end{array}$ \\
\hline $\begin{array}{l}\text { Most reported period: } \\
\sim 1984\end{array}$ & $73 \%$ \\
\hline \multicolumn{2}{|l|}{ Agriculture } \\
\hline Reports of alterations & $50 \%$ \\
\hline $\begin{array}{l}\text { Types of alteration: } \\
\text { Pest incidence } \\
\text { Decrease in productivity }\end{array}$ & $\begin{array}{l}19 \% \\
46 \%\end{array}$ \\
\hline
\end{tabular}


Based on our results, we are confident that those metrics can be used to guide conservation initiatives aiming to preserve and/or to recover the original potential of Amazon floodplain for providing ES to a population highly dependent on them, mainly in periods of economic crises at the end of affluence cycles. In this sense, the results can also be used as input for modeling future scenarios of flooded forest conversion to pasture land in response to different public polices for reducing Amazon upland deforestation $[18,112,113]$. A series of innovative approaches are available in the literature to build scenarios using agent based model which include population perception on the definition of policies to reduce impacts of land use change on environmental services [114-116]. Those simulations would also be able to project the state of ES in different scenarios of conservation policies, in order to help a wide understand of the risks of forest fragmentation not only to local population but also at national level, since the degradation of floodplain ES will affect not only forest dependent species but all the biota and the ecological processes in the floodplain [113].

\section{Conclusions}

The present study provides evidence of the accelerated process of degradation of the floodplain forest of the Lower Amazon, and reinforces the importance of the integrity of floodplain forest ecosystem for the maintenance of biodiversity and for the provision of ES to the riverine populations. Between 1975 and 2008, there was a reduction of almost three quarters of the forest habitat, as well as important changes in the landscape structure that resulted in a high degree of fragmentation. The analyses of the landscape structure and dynamics point to a series of negative ecological effects on the tree, bird, mammal and insect communities of the region, such as the high probability of local extinction, declining biodiversity and alterations in the species distribution in the patches. Many affected species play an essential role in the provision of ES to the riverine populations, as they act at different trophic levels (producers, herbivores, omnivores, carnivores and detritivores), constitute important sources of food and other resources, and act as pollinators, decomposers, seed dispersers, and pest and disease regulators.

The field information corroborates the inferences with respect to the impacts of fragmentation on the provision of ES. Almost all of the visited communities reported negative alterations in the local fauna and flora in the last three decades, such as forest habitat loss and a decrease in the variety and/or abundance of animal and plant species that constitute important sources of resources for these populations. According to the riverine residents, the mammals are the most prejudiced, and around one quarter of the recognized species were scarce or locally extinct due to hunting in the last 20-30 years. Landscape results also show greater impacts on mammals, particularly for sensitive, large-sized species that have specific requirements in terms of living area. Furthermore, almost half of the interviewees reported a decrease in agricultural crop productivity, and a quarter of them confirm a higher incidence of pests in the last 30 years.

In this context, the compiled data indicate that the provision of the ES of the landscape has become highly compromised in recent decades, with great damage to the biodiversity of trees, birds, mammals and insects, and the consequent decline in the sources (animal and plant) of food, fire wood, raw material and medicines for the riverine populations, as well as lower agricultural productivity due to the lack of pollination, impoverishment of the soil and increase of pests.

The results reinforce the assumption that the landscape structure is related to its capacity to provide ES. Therefore, given the understanding of this relationship, it is possible to infer the degree of service provision based on the analysis of the respective landscape. This type of approach can be used as a tool for prospecting the degree of compromise of the biodiversity and the provision of ES across extensive, remote and relatively unstudied landscapes such as the Amazon floodplains. However, the importance of using data on local human populations in studies of ES is evident, particularly when these populations are dependent on and vulnerable to changes in the provision of services, as is the case with riverine populations in the floodplain. Not only do these data complement and validate the landscape analysis, but they also provide information about the response time and degree of impact on 
the affected populations, allowing a better understanding of the connections between ES and human well-being in the region.

The next steps for this research include: (1) the acquisition of ecological field data for a robust validation of this methodology, indicating the degree of accuracy of the inferences made based on the landscape and environmental perception of the riverine communities; and (2) the collection of data on the well-being of riverine communities. These data should encompass the multiple dimensions of human well-being, which include objective components (income, work, etc.) as well as subjective components (life satisfaction, autonomy, etc.). The reason for this is because the degradation of the natural habitat does not always have an isotropic impact on the various components of well-being, particularly when this degradation is accompanied by economic development in the region. This approach is already being applied in different floodplain landscapes of the Amazon-Solimões River and will permit, in further studies, a more adequate assessment of the impacts of forest fragmentation on the provision of ES and on the well-being of the riverine populations in the Amazon floodplain.

Supplementary Materials: The following are available online at www.mdpi.com/2072-4292/8/11/886/s1, Table S1: Studies reviewed in Section 3.2.

Acknowledgments: The authors wish to acknowledge the Brazilian National Council for Scientific and Technological Development (CNPq) for the financial support during the field campaigns (Process 301276/2010-2), and the São Paulo Research Foundation (FAPESP) for the fellowship supporting Vivian Renó through her graduate program (Process 2012/02544-5) and for the financial support during the field campaigns (Process 2011/23594-8). The authors also thank the anonymous reviewers for their valuable comments on the manuscript.

Author Contributions: The study was conceived and designed by Vivian Renó and Evlyn Novo. Vivian Renó was responsible for data collection and processing. Data analysis and interpretation was conducted primarily by Vivian Renó, with important contributions from Evlyn Novo and Maria Escada. The manuscript was written by Vivian Renó with assistance from Evlyn Novo.

Conflicts of Interest: The authors declare no conflict of interest.

\section{References}

1. Millennium Ecosystem Assessment. Ecosystems and Human Well-Being: A Framework for Assessment; Island Press: Washington, DC, USA, 2003.

2. DeGroot, R.S.; Alkemade, R.; Braat, L.; Hein, L.; Willemen, L. Challenges in integrating the concept of ecosystem services and values in landscape planning, management and decision making. Ecol. Complex. 2010, 7, 260-272. [CrossRef]

3. Ash, N.; Blanco, H.; Brown, C.; Garcia, K.; Henrichs, T.; Lucas, N.; Raudsepp-Hearne, C.; Simpson, R.D.; Scholes, R.; Tomich, T.P.; et al. Ecosystems and Human Well-Being: A Manual for Assessment Practitioners; Island Press: Washington, DC, USA; Covelo, CA, USA; London, UK, 2010.

4. Ewel, K.C. Appreciating tropical coastal wetlands from a landscape perspective. Front. Ecol. Environ. 2010, 8, 20-26. [CrossRef]

5. Millennium Ecosystem Assessment. Ecosystems and Human Well-Being: Synthesis-Wetlands and Water; Island Press: Washington, DC, USA, 2005.

6. Hess, L.L.; Melack, J.M.; Affonso, A.G.; Barbosa, C.; Gastil-Buhl, M.; Novo, E.M.L.M. Wetlands of the Lowland Amazon Basin: Extent, Vegetative Cover, and Dual-season Inundated Area as Mapped with JERS-1 Synthetic Aperture Radar. Wetlands 2015, 35, 745-756. [CrossRef]

7. Goulding, M.; Smith, N.; Mahar, D. Floods of Fortune: Ecology and Economy along the Amazon; Columbia University Press: New York, NY, USA, 1996.

8. Ohly, J.J. Development of Central Amazonia in the Modern era. In The Central Amazon Floodplain: Actual Use and Options for a Sustainable Management; Junk, W.J., Ohly, J.J., Soares, M.G.M., Eds.; Backhuys Publishers: Leiden, The Netherlands, 2000.

9. Schöngart, J. Growth-Oriented Logging (GOL): A new concept towards sustainable forest management in Central Amazonian várzea floodplains. For. Ecol. Manag. 2008, 256, 46-58. [CrossRef]

10. Wittmann, F.; Wittmann, A.O. Use of Amazonian floodplain trees. In Amazonian Floodplain Forests: Ecophysiology, Biodiversity and Sustainable Management; Junk, W.J., Piedade, M.T.F., Wittmann, F., Schongart, J., Parolin, P., Eds.; Springer: Berlin, Germany, 2010; pp. 389-418. 
11. IBGE Population Census 2010: Brazilian Institute of Geography and Statistics (IBGE) Brazilian Institute of Geography and Statistics. Available online: http://www.ibge.gov.br/ (accessed on 1 January 2015).

12. McGrath, D.G.; Almeida, O.T.; Merry, F.D. The influence of community management agreements on household economic strategies: Cattle grazing and fishing agreements on the Lower Amazon floodplain. Int. J. Commons 2007, 1, 67-87. [CrossRef]

13. Somoza, R.C.D. Impacto do Desflorestamento na Velocidade de Propagação da Água em Zonas de Várzea do Baixo Amazonas; Instituto Nacional de Pesquisas Espaciais (INPE): São José dos Campos, Brazil, 2015.

14. Bayley, P.B. Understanding large river: Floodplain ecosystems. Bioscience 1995, 45, 153-158. [CrossRef]

15. Malmqvist, B.; Rundle, S. Threats to the running water ecosystems of the world. Environ. Conserv. 2002, 29, 134-153. [CrossRef]

16. Castello, L.; McGrath, D.G.; Hess, L.L.; Coe, M.T.; Lefebvre, P.A.; Petry, P.; Macedo, M.N.; Renó, V.F.; Arantes, C.C. The vulnerability of Amazon freshwater ecosystems. Conserv. Lett. 2013, 6, 217-229. [CrossRef]

17. Renó, V.F.; Novo, E.M.L.M.; Suemitsu, C.; Rennó, C.D.; Silva, T.S.F. Assessment of deforestation in the Lower Amazon floodplain using historical Landsat MSS/TM imagery. Remote Sens. Environ. 2011, 115, 3446-3456. [CrossRef]

18. Winklerprins, A.M.G.A. Jute cultivation in the lower Amazon, 1940-1990: An ethnographic account from Santarém, Pará, Brazil. J. Hist. Geogr. 2006, 32, 818-838. [CrossRef]

19. Barbarisi, B.F.; Renó, V.F.; Barbosa, C.C.F.; Novo, E.M.L.M. Integração de dados censitários e de sensoriamento remoto para estimar o rebanho bovino e bubalino da várzea do Baixo Amazonas. In Novas Tecnologias para o Monitoramento e Estudo de Reservatórios Hidrelétricos e Grandes Lagos; Alcântara, E.H., Novo, E.M.L.M., Stech, J.L., Eds.; Parêntese Editora: São José dos Campos, Brazil, 2010; Volume 1, pp. 257-273.

20. Barros, A.C.; Uhl, C. Padrões, Problemas e Potencial da Extração Madeireira ao Longo do Rio Amazonas e do seu Estuário; IMAZOM: Belém, Brasil, 1997; Volume 4.

21. Sheikh, P.A.; Merry, F.D.; McGrath, D.G. Water buffalo and cattle ranching in the Lower Amazon Basin: Comparisons and conflicts. Agric. Syst. 2006, 87, 313-330. [CrossRef]

22. Renó, V.F.; Novo, E.M.L.M. Alterações da paisagem de várzea do Baixo Amazonas entre 1970 e 2008. In Anais XVI Simpósio Brasileiro de Sensoriamento Remoto-SBSR; Instituto Nacional de Pesquisas Espaciais (INPE): Foz do Iguaçu, Brasil, 2013; pp. 7778-7785.

23. Fu, B.; Wang, S.; Su, C.; Forsius, M. Linking ecosystem processes and ecosystem services. Curr. Opin. Environ. Sustain. 2013, 5, 4-10. [CrossRef]

24. Naeem, S.; Bunker, D.E.; Hector, A.; Loreau, M.; Perrings, C. Biodiversity, Ecosystem Functioning, and Human Wellbeing: An Ecological and Economic Perspective; Naeem, S., Bunker, D.E., Hector, A., Loreau, M., Perrings, C., Eds.; Oxford University Press: New York, NY, USA, 2009.

25. Naveh, Z. Landscape ecology and sustainability. Landsc. Ecol. 2007, 22, 1437-1440. [CrossRef]

26. Turner, M.G.; Donato, D.C.; Romme, W.H. Consequences of spatial heterogeneity for ecosystem services in changing forest landscapes: Priorities for future research. Landsc. Ecol. 2013, 28, 1081-1097. [CrossRef]

27. Farwig, N.; Bailey, D.; Bochud, E.; Herrmann, J.D.; Kindler, E.; Reusse, N.; Schuepp, C.; Martin, H.; Schmidt-Entling, M.H. Isolation from forest reduces pollination, seed predation and insect scavenging in Swiss farmland. Landsc. Ecol. 2009, 24, 919-927. [CrossRef]

28. Kruess, A.; Tscharntke, T. Habitat fragmentation, species loss, and biological control. Science 1994, 264, 1581-1584. [CrossRef] [PubMed]

29. Marichal, R.; Grimaldi, M.; Feijoo, M.A.; Oszwald, J.; Praxedes, C.; Ruiz Cobo, D.H.; del Pilar Hurtado, M.; Desjardins, T.; da Silva Junior, M.L.; da Silva Costa, L.G.; et al. Soil macroinvertebrate communities and ecosystem services in deforested landscapes of Amazonia. Appl. Soil Ecol. 2014, 83, 177-185. [CrossRef]

30. Ouyang, W.; Skidmore, A.K.; Hao, F.; Wang, T. Soil erosion dynamics response to landscape pattern. Sci. Total Environ. 2010, 408, 1358-1366. [CrossRef] [PubMed]

31. Ricketts, T.H.; Regetz, J.; Steffan-Dewenter, I.; Cunningham, S.A.; Kremen, C.; Bogdanski, A.; Gemmill-Herren, B.; Greenleaf, S.S.; Klein, A.M.; Mayfield, M.M.; et al. Landscape effects on crop pollination services: Are there general patterns? Ecol. Lett. 2008, 11, 499-515. [CrossRef] [PubMed]

32. Burkhard, B.; Kroll, F.; Müller, F. Landscapes' Capacities to Provide Ecosystem Services-A Concept for Land-Cover Based Assessments. Landsc. Online 2009, 15, 1-22. [CrossRef] 
33. Ferraz, S.F.B.; Ferraz, K.M.P.M.B.; Cassiano, C.C.; Brancalion, P.H.S.; Luz, D.T.A.; Azevedo, T.N.; Tambosi, L.R.; Metzger, J.P. How good are tropical forest patches for ecosystem services provisioning? Landsc. Ecol. 2014, 29, 187-200. [CrossRef]

34. Franco, D.; Mannino, I.; Zanetto, G. The impact of agroforestry networks on scenic beauty estimation: The role of a landscape ecological network on a socio-cultural process. Landsc. Urban Plan. 2003, 62, 119-138. [CrossRef]

35. Frank, S.; Fürst, C.; Koschke, L.; Makeschin, F. A contribution towards a transfer of the ecosystem service concept to landscape planning using landscape metrics. Ecol. Indic. 2012, 21, 30-38. [CrossRef]

36. Haines-Young, R.; Potschin, M.; Kienast, F. Indicators of ecosystem service potential at European scales: Mapping marginal changes and trade-offs. Ecol. Indic. 2012, 21, 39-53. [CrossRef]

37. Junk, W.J.; Bayley, P.B.; Sparks, R.E. The Flood Pulse Concept in River-Floodplain Systems. Int. Large River Symp. 1989, 106, 110-127.

38. ANA National Water Agency Brazil (ANA). HidroWeb. Available online: http://www.snirh.gov.br/ hidroweb/ (accessed on 1 July 2015).

39. Benchimol, M.; Peres, C.A. Edge-mediated compositional and functional decay of tree assemblages in Amazonian forest islands after 26 years of isolation. J. Ecol. 2015, 103, 408-420. [CrossRef]

40. Kapos, V.; Ganade, G.; Matsui, E.; Victoria, R.L. $\partial^{\wedge} 13 \mathrm{C}$ as an indicator of edge effects in tropical rainforest reserves. J. Ecol. 1993, 81, 425-432. [CrossRef]

41. Laurance, W.F.; Ferreira, L.V.; Rankin-de Merona, J.M.; Laurance, S.G. Rain forest fragmentation and the dynamics of Amazonian tree communities. Ecology 1998, 79, 2032-2040. [CrossRef]

42. Laurance, W.F.; Lovejoy, T.E.; Vasconcelos, H.L.; Bruna, E.M.; Didham, R.K.; Stouffer, P.C.; Gascon, C.; Bierregaard, R.O.; Laurance, S.G.; Sampaio, E. Ecosystem decay of Amazonian forest fragments: A 22-year investigation. Conserv. Biol. 2002, 16, 605-618. [CrossRef]

43. Metzger, J.P. Tree functional group richness and landscape structure in a brazilian tropical fragmented landscape. Ecol. Appl. 2000, 10, 1147-1161. [CrossRef]

44. Michalski, F.; Nishi, I.; Peres, C.A. Disturbance-mediated drift in tree functional groups in Amazonian forest fragments. Biotropica 2007, 39, 691-701. [CrossRef]

45. Santos, B.A.; Tabarelli, M.; Melo, F.P.L.; Camargo, L.C.; Andrade, A.; Laurance, S.G.; Laurance, W.F. Phylogenetic Impoverishment of Amazonian Tree Communities in an Experimentally Fragmented Forest Landscape. PLoS ONE 2014, 9, e113109. [CrossRef] [PubMed]

46. Lees, A.C.; Peres, C.A. Avian life-history determinants of local extinction risk in a hyper-fragmented neotropical forest landscape. Anim. Conserv. 2008, 11, 128-137. [CrossRef]

47. Lees, A.C.; Peres, C.A. Gap-crossing movements predict species occupancy in Amazonian forest fragments. Oikos 2009, 118, 280-290. [CrossRef]

48. Lovejoy, T.E.; Bierregaard, R.O.; Rylands, A.B.; Malcom, J.R.; Quintela, C.E.; Harper, L.H.H.; Brown, K.S.; Powell, A.H.; Powell, G.V.N.; Shubart, H.O.R.; et al. Edge and other effects of isolation on Amazon forest fragments. In Conservation Biology: The Science of Scarcity and Diversity; Soulé, M.E., Ed.; Sinauer Associates: Sunderland, MA, USA, 1986; pp. 257-285.

49. Stouffer, P.C.; Bierregaard, R.O. Effects of Forest Fragmentation on Understory Hummingbirds in Amazonian Brazil. Conserv. Biol. 1995, 9, 1085-1094. [CrossRef]

50. Stouffer, P.C.; Bierregaard, R.O. Use of Amazonian Forest Fragments by Understory Insectivorous Birds. Ecology 1995, 76, 2429-2445. [CrossRef]

51. Stratford, J.A.; Stouffer, P.C. Local extinctions of terrestrial insectivorous birds in a fragmented landscape near Manaus, Brazil. Conserv. Biol. 1999, 13, 1416-1423. [CrossRef]

52. Stratford, J.A.; Stouffer, P.C. Forest fragmentation alters microhabitat availability for Neotropical terrestrial insectivorous birds. Biol. Conserv. 2015, 188, 109-115. [CrossRef]

53. Lees, A.C.; Peres, C.A. Conservation value of remnant riparian forest corridors of varying quality for Amazonian birds and mammals. Conserv. Biol. 2008, 22, 439-449. [CrossRef] [PubMed]

54. Lyra-Jorge, M.C.; Ribeiro, M.C.; Ciocheti, G.; Tambosi, L.R.; Pivello, V.R. Influence of multi-scale landscape structure on the occurrence of carnivorous mammals in a human-modified savanna, Brazil. Eur. J. Wildl. Res. 2009, 56, 359-368. [CrossRef]

55. Michalski, F.; Peres, C.A. Disturbance-Mediated Mammal Persistence and Abundance-Area Relationships in Amazonian Forest Fragments. Conserv. Biol. 2007, 21, 1626-1640. [CrossRef] [PubMed] 
56. Santos-Filho, M.; Peres, C.A.; Silva, D.J.; Sanaiotti, T.M. Habitat patch and matrix effects on small-mammal persistence in Amazonian forest fragments. Biodivers. Conserv. 2012, 21, 1127-1147. [CrossRef]

57. Stevens, S.M.; Husband, T.P. The influence of edge on small mammals: Evidence from Brazilian Atlantic forest fragments. Biol. Conserv. 1998, 85, 1-8. [CrossRef]

58. Bianchi, F.J.J.A.; Booij, C.J.H.; Tscharntke, T. Sustainable pest regulation in agricultural landscapes: A review on landscape composition, biodiversity and natural pest control. Proc. Biol. Sci. 2006, 273, 1715-1727. [CrossRef] [PubMed]

59. Brosi, B.J.; Daily, G.C.; Ehrlich, P.R. Bee community shifts with landscape context in a tropical countryside. Ecol. Appl. 2007, 17, 418-430. [CrossRef] [PubMed]

60. Brown, C.; Albrecht, C. The Effect of Tropical Deforestation on Stingless Bees of the Genus Melipona (Insecta: Hymenoptera: Apidae: Meliponini) in Central Rondonia, Brazil. J. Biogeogr. 2001, 28, 623-634. [CrossRef]

61. Carvalho, K.S.; Vasconcelos, H.L. Forest fragmentation in central Amazonia and its effects on litter-dwelling ants. Biol. Conserv. 1999, 91, 151-157. [CrossRef]

62. Didham, R.K.; Ghazoul, J.; Stork, N.E.; Davis, A.J. Insects in fragmented forests: A functional approach. Trends Ecol. Evol. 1996, 11, 255-260. [CrossRef]

63. Dohm, C.; Leal, I.R.; Tabarelli, M.; Meyer, S.T.; Wirth, R.; Dohm, C.; Leal, I.R.; Tabarelli, M.; Meyer, S.T.; Wirth, R. Leaf-cutting ants proliferate in the Amazon: an expected response to forest edge? J. Trop. Ecol. 2011, 27, 645-649. [CrossRef]

64. Guimarães, C.; Viana, J.P.R.; Cornelissen, T. A meta-analysis of the effects of fragmentation on herbivorous insects. Environ. Entomol. 2014, 43, 537-545. [CrossRef] [PubMed]

65. Hadley, A.S.; Betts, M.G. The effects of landscape fragmentation on pollination dynamics: Absence of evidence not evidence of absence. Biol. Rev. Camb. Philos. Soc. 2012, 87, 526-544. [CrossRef] [PubMed]

66. Ricketts, T.H.; Williams, N.M.; Mayfield, M.M. Connectivity and ecosystem services: crop pollination in agricultural landscapes. In Connectivity Conservation; Crooks, K.R., Sanjayan, M.A., Eds.; Cambridge University Press: Cambridge, UK, 2006; pp. 255-290.

67. Powell, A.; Powell, G. Population dynamics of male euglossine bees in Amazonian forest fragments. Biotropica 1987, 19, 176-179. [CrossRef]

68. Kruess, A.; Tscharntke, T. Species richness and parasitism in a fragmented landscape: Experiments and field studies with insects on Vicia sepium. Oecologia 2000, 122, 129-137. [CrossRef]

69. Urbas, P.; Araújo, M.V., Jr.; Leal, I.R.; Wirth, R. Cutting more from cut forests: Edge effects on foraging and herbivory of leaf-cutting ants in Brazil. Biotropica 2007, 39, 489-495. [CrossRef]

70. Brown, K.S. Diversity, disturbance, and sustainable use of Neotropical forests: Insects as indicators for conservation monitoring. J. Insect Conserv. 1997, 1, 25-42. [CrossRef]

71. Wittmann, F.; Junk, W.J.; Piedade, M.T.F. The várzea forests in Amazonia: flooding and the highly dynamic geomorphology interact with natural forest succession. For. Ecol. Manag. 2004, 196, 199-212. [CrossRef]

72. Wittmann, F.; Schöngart, J.; Montero, J.C.; Motzer, T.; Junk, W.J.; Piedade, M.T.F.; Queiroz, H.L.; Worbes, M. Tree species composition and diversity gradients in white-water forests across the Amazon Basin. J. Biogeogr. 2006, 33, 1334-1347. [CrossRef]

73. Bispo, P.D.C.; Valeriano, M.D.M.; Kuplich, T.M. Variáveis geomorfométricas locais e sua relação com a vegetação da região do interflúvio Madeira-Purus (AM-RO). Acta Amazon. 2009, 39, 81-90. [CrossRef]

74. Definiens. Definiens Professional 5: Reference Book; Definiens, Ed.; The Imaging Intelligence Company: Munich, Germany, 2006.

75. Desclée, B.; Bogaert, P.; Defourny, P. Forest change detection by statistical object-based method. Remote Sens. Environ. 2006, 102, 1-11. [CrossRef]

76. Baatz, M.; Schäpe, A. Multiresolution Segmentation-An optimization approach for high quality multi-scale image segmentation. In Proceedings of the XII Angewandte Geographische Informationsverarbeitung, Salzburg, Austria, 5-7 July 2000; pp. 12-23.

77. Definiens. Definiens Developer 7: User Guide; Definiens, Ed.; The Imaging Intelligence Company: Munich, Germany, 2008.

78. Hess, L.L.; Melack, J.M.; Novo, E.M.L.M.; Barbosa, C.C.F. Dual-season mapping of wetland inundation and vegetation. Remote Sens. Environ. 2003, 87, 404-428. [CrossRef] 
79. Melack, J.M.; Hess, L.L. Remote Sensing of the Distribution and Extent of Wetlands in the Amazon Basin. In Amazonian Floodplain Forests: Ecophysiology, Biodiversity and Sustainable Management; Junk, W.J., Piedade, M.T.F., Wittmann, F., Schöngart, J., Parolin, P., Eds.; Springer: Berlin/Heidelberg, Germany, 2010; Volume 210, pp. 43-59.

80. Rennó, C.D.; Novo, E.M.L.M.; Banon, L.C. Correção geométrica da máscara de áreas alagáveis da bacia amazônica. In XVI Simpósio Brasileiro de Sensoriamento Remoto; Instituto Nacional de Pesquisas Espaciais (INPE): Foz do Iguaçu, Brasil, 2013; pp. 5507-5514.

81. Ferreira, R.D.; Leão, J.A.D.; Silva, T.S.F.; Rennó, C.D.; Novo, E.M.L.M.; Barbosa, C.C.F. Atualização e correção do delineamento de áreas alagáveis para a bacia Amazônica. In XVI Simpósio Brasileiro de Sensoriamento Remoto; Instituto Nacional de Pesquisas Espaciais (INPE): Foz do Iguaçu, Brasil, 2013; pp. 5864-5871.

82. Novo, E.M.L.M. Relatório Projeto Geoma: Efeito de Perturbações Antrópicas Sobre a Estrutura Florística e Funcionamento das Florestas de Várzea e seu Impacto Sobre os Ecossistemas Aquáticos da Calha Central do Solimões-Amazonas; Instituto Nacional de Pesquisas Espaciais (INPE): São José dos Campos, Brasil, 2013.

83. ArcGIS Desktop; Environmental Systems Research Institute (ESRI): Redlands, CA, USA, 2012.

84. McGarigal, K.; Marks, B. FRAGSTATS: Spatial Pattern Analysis Program for Quantifying Landscape Structure; FRAGSTATS: Corvallis, OR, USA, 1994.

85. Junk, W.J. The Central Amazon Floodplain: Ecology of a Pulsing System; Springer: Berlin, Germany, 1997.

86. Junk, W.J.; Piedade, M.T.F. The Amazon River basin. In The World's Largest Wetlands; Fraser, H., Keddy, A., Eds.; Cambridge University Press: Cambridge, UK, 2005; pp. 63-117.

87. Parolin, P.; de Simone, O.; Haase, K.; Waldhoff, D.; Rottenberger, S.; Kuhn, U.; Kesselmeier, J.; Kleiss, B.; Schmidt, W.; Piedade, M.T.F.; et al. Central Amazonian Floodplain Forests: Tree Adaptations in a Pulsing System. Bot. Rev. 2004, 70, 357-380. [CrossRef]

88. Universidade Federal do Amazonas (UFAM). Comunidades Ribeirinhas Amazônicas: Modos de Vida e uso dos Recursos Naturais; de Fraxe, T.J.P., Pereira, H.S., Witkoski, A.C., Eds.; UFAM: Manaus, Brasil, 2007.

89. Instituto de Pesquisa Ambiental da Amazônia (IPAM). Projeto Básico de Desenvolvimento Sustentável do Assentamento Agroextrativista: Urucurituba; IPAM: Santarém, Portugal, 2010.

90. Ariti, A.T.; Vliet, J.V.; Verburg, P.H. Land-use and land-cover changes in the Central Rift Valley of Ethiopia: Assessment of perception and adaptation of stakeholders. Appl. Geogr. 2015, 65, 28-37. [CrossRef]

91. Tasser, E.; Walde, J.; Tappeiner, U.; Teutsch, A.; Noggler, W. Land-use changes and natural reforestation in the Eastern Central Alps. Agric. Ecosyst. Environ. 2007, 118, 115-129. [CrossRef]

92. Mottet, A.; Ladet, S.; Coqué, N.; Gibon, A. Agricultural land-use change and its drivers in mountain landscapes: A case study in the Pyrenees. Agric. Ecosyst. Environ. 2006, 114, 296-310. [CrossRef]

93. Malek, Ž.; Scolobig, A.; Schröter, D. Understanding land cover changes in the Italian Alps and Romanian Carpathians combining remote sensing and stakeholder interviews. Land 2014, 3, 52-73. [CrossRef]

94. Leitão, S.; da Falcão, J.T.R.; Maluf, M.R. Ethical Standards of Scientific Research Involving Human Subjects in Brazil: Perspectives Concerning Psychology. Psicol. Reflexão e Crítica 2015, 28, 40-48. [CrossRef]

95. De Castro-Santos, L.A. A critique of Brazil's current research ethics committees. História Ciências Saúde-Manguinhos 2014, 21, 364-366.

96. Richards, P.W. The Tropical Rain Forest, 2nd ed.; Cambridge University Press: Cambridge, UK, 1996.

97. Michel, N.L.; Sherry, T.W.; Carson, W.P. The omnivorous collared peccary negates an insectivore-generated trophic cascade in Costa Rican wet tropical forest understorey. J. Trop. Ecol. 2013, 30, 1-11. [CrossRef]

98. Stratford, J.A.; Şekercioğlu, Ç.H. Birds in Forest Ecosystems. In Handbook of Forest Ecology; Corlett, R., Peh, K., Bergeron, Y., Eds.; Routeledge Press: London, UK, 2015; pp. 281-296.

99. Jones, K.E.; Safi, K. Ecology and evolution of mammalian biodiversity. Philos. Trans. R. Soc. B 2011, 366, 2451-2461. [CrossRef] [PubMed]

100. Henle, K.; Davies, K.F.; Kleyer, M.; Margules, C.; Settele, J. Predictors of species sensitivity to fragmentation. Biodivers. Conserv. 2004, 13, 207-251. [CrossRef]

101. Wilcox, B.A.; Murphy, D.D. Conservation Strategy: The Effects of Fragmentation on Extinction. Am. Nat. 1985, 125, 879-887. [CrossRef]

102. Seastedt, T.R.; Crossley, D.A. The Influence of Arthropods on Ecosystems. Bioscience 1984, 34, $157-161$. [CrossRef]

103. Kerr, W.E. A importância da meliponicultura para o país. Rev. Biotecnol. Ciência Desenvolv. 1997, 1, 42-44. 
104. Kerr, W.E.; Carvalho, G.A.; Silva, A.C.; Assis, M.G.P. Aspectos pouco mencionados da biodiversidade amazônica. Mensagem Doce 2001, 80, 45-60.

105. Barreto, L.S.; Teixeira, A.F.R. Manejo Avançado e Conservação de Meliponíneos. In Congresso Brasileiro de Apicultura; Confederação Brasileira de Apicultura (CBA): Aracajú, Brasil, 2006.

106. Silveira-Neto, S.; Monteiro, R.C.; Zucchi, R.A.; Moraes, R.C.B. Uso da análise faunística de insetos na avaliação do impacto ambiental. Sci. Agric. 1993, 52, 9-15. [CrossRef]

107. Hammond, P.C.; Miller, J.C. Comparison of the Biodiversity of Lepidoptera within Three Forested Ecosystems. Ann. Entomol. Soc. Am. 1998, 91, 323-328. [CrossRef]

108. Marengo, J.A.; Espinoza, J.C. Extreme seasonal droughts and floods in Amazonia: Causes, trends and impacts. Int. J. Climatol. 2016, 36, 1033-1050. [CrossRef]

109. Forzieri, G.; Degetto, M.; Righetti, M.; Castelli, F.; Preti, F. Satellite multispectral data for improved floodplain roughness modelling. J. Hydrol. 2011, 407, 41-57. [CrossRef]

110. Peres, C.A. Synergistic Effects on Amazonian Forest Vertebrates Fragmentation. Conserv. Biol. 2001, 15, 1490-1505. [CrossRef]

111. Tabarelli, M.; Cardoso da Silva, J.M.; Gascon, C. Forest fragmentation, synergisms and the impoverishment of netropical forests. Biodivers. Conserv. 2004, 13, 1419-1425. [CrossRef]

112. McGrath, D.G.; Cardoso, A.; Almeida, O.T.; Pezzuti, J. Constructing a policy and institutional framework for an ecosystem-based approach to managing the Lower Amazon floodplain. Environ. Dev. Sustain. 2008, 10, 677-695. [CrossRef]

113. Lobón-Cerviá, J.; Hess, L.L.; Melack, J.M.; Araujo-Lima, C.A. The importance of forest cover for fish richness and abundance on the Amazon floodplain. Hydrobiologia 2015, 750, 245-255. [CrossRef]

114. Maeda, E.E.; de Almeida, C.M.; de Carvalho Ximenes, A.; Formaggio, A.R.; Shimabukuro, Y.E.; Pellikka, P. Dynamic modeling of forest conversion: Simulation of past and future scenarios of rural activities expansion in the fringes of the Xingu National Park, Brazilian Amazon. Int. J. Appl. Earth Observ. Geoinform. 2011, 13, 435-446. [CrossRef]

115. Malek, Z.; Boerboom, L. Participatory Scenario Development to Address Potential Impacts of Land Use Change: An Example from the Italian Alps. Mt. Res. Dev. 2015, 35, 126-138. [CrossRef]

116. Van Berkel, D.B.; Verburg, P.H. Combining exploratory scenarios and participatory backcasting: Using an agent-based model in participatory policy design for a multi-functional landscape. Landsc. Ecol. 2012, 27, 641-658. [CrossRef] [PubMed] 